Article

\title{
New Microporous Lanthanide Organic Frameworks. Synthesis, Structure, Luminescence, Sorption, and Catalytic Acylation of 2-Naphthol
}

\author{
Dana Bejan ${ }^{1, *}$, Lucian Gabriel Bahrin ${ }^{1}$, Sergiu Shova ${ }^{1}{ }^{\mathbb{D}}$, Narcisa Laura Marangoci ${ }^{1}$, \\ Ülkü Kökçam-Demir ${ }^{2}$, Vasile Lozan ${ }^{1,3, *}$ and Christoph Janiak ${ }^{2, *(D)}$ \\ 1 "Petru Poni" Institute of Macromolecular Chemistry, Romanian Academy, 700487 Iasi, Romania; \\ bahrin.lucian@icmpp.ro (L.G.B.); shova@icmpp.ro (S.S.); nmarangoci@icmpp.ro (N.L.M.) \\ 2 Institut für Anorganische Chemie und Strukturchemie, Heinrich-Heine Universität Düsseldorf, \\ Universitätsstr. 1, D 40225 Düsseldorf, Germany; Uelkue.Koekcam@uni-duesseldorf.de \\ 3 Institute of Chemistry of MECR, Academiei str. 3, MD2028 Chisinau, Moldova \\ * Correspondence: bejan.dana@icmpp.ro (D.B.); lozan.vasile@icmpp.ro (V.L.); janiak@uni-duesseldorf.de (C.J.)
}

Academic Editors: Irina Savina and T. Jean Daou

Received: 18 June 2020; Accepted: 2 July 2020; Published: 3 July 2020

\begin{abstract}
New metal-organic frameworks (MOF) with lanthanum(III), cerium(III), neodymium(III), europium(III), gadolinium(III), dysprosium(III), and holmium(III)] and the ligand precursor 1,3,5-tris(4-carboxyphenyl)-2,4,6-trimethylbenzene $\left(\mathrm{H}_{3} \mathrm{~L}\right)$ were synthesized under solvothermal conditions. Single crystal $\mathrm{x}$-ray analysis confirmed the formation of three-dimensional frameworks of $\left[\mathrm{LnL}\left(\mathrm{H}_{2} \mathrm{O}\right)_{2}\right]_{n} \cdot x \mathrm{DMF} \cdot \mathrm{yH}_{2} \mathrm{O}$ for $\mathrm{Ln}=\mathrm{La}, \mathrm{Ce}$, and Nd. From the nitrogen sorption experiments, the compounds showed permanent porosity with Brunauer-Emmett-Teller (BET) surface areas of about $400 \mathrm{~m}^{2} / \mathrm{g}$, and thermal stability up to $500{ }^{\circ} \mathrm{C}$. Further investigations showed that these Ln-MOFs exhibit catalytic activity, paving the way for potential applications within the field of catalysis.
\end{abstract}

Keywords: metal-organic frameworks; lanthanides; luminescence; sorption; catalysis

\section{Introduction}

Metal-organic frameworks (MOFs) form a class of porous materials that have been intensively studied in the last decade [1-6]. MOFs provide diverse and easily modifiable architectures and topologies and play important roles in synthetic chemistry [7], catalysis [2,8-10], molecular separation [11], magnetism [12,13], optics [14,15] possess luminescence [16,17], and are used as potential drug delivery carriers [18-20]. Mostly, MOFs are of interest [21-23] as microporous materials in gas/solvent sorption applications due to their high porosity and tunable pore structure. Amongst the intensely studied carboxylate ligands is 1,3,5-benzenetricarboxylate, the trianion of trimesic acid (TMA) [24,25]. Extended derivatives of TMA, namely 1,3,5-benzenetribenzoic acid (BTBA) and mesitylenetribenzoic acid (MTBA) are also exploited as organic spacers in MOFs (see Figure 1).

MOFs designed with these ligands exhibit properties and functions that are attractive to researchers due to their rigidity and trifunctional identity [26-28]. Even though the BTBA and MTBA systems are at first glance quite similar, their geometries differ markedly. The three methyl groups in MTBA induce steric hindrance and lead to a structure in which the three carboxylate groups are almost $90^{\circ}$ out of plane with the central benzene moiety. Attempts to crystallize BTBA and establish its crystal structure have been unsuccessful thus far [29], while hydrogen bond-mediated self-assembly of MTBA was found to result in honeycomb networks with enlarged pores of ca. 24-26 $\AA$ in diameter, which can accommodate $\mathrm{K}^{+}$-coordinated 18 -crown- 6 and dibenzo-18-crown- 6 , as shown by a series of $x$-ray diffraction structures reported recently [30]. BTBA and MTBA were used in the development of 
new design strategies for MOF materials with the desired porosity, pore size, and functionality [31]. Mixed-ligand Archimedian polyhedron-based MOFs assembled from equilateral triangles (BTBA or MTBA) and squares (porphyrin) were shown to be efficient photocatalysts for $\mathrm{CO}_{2}$ reduction upon visible light irradiation [31]. Mesoporous MOFs consisting of $\mathrm{M}_{6}$ nodes $(\mathrm{M}=\mathrm{Zr}, \mathrm{Hf}, \mathrm{Ce}, \mathrm{Th})$ and MTBA as a tritopic linker have been prepared and used as supporting materials for a vanadium catalyst in the aerobic oxidation of 4-methylbenzyl alcohol [32].

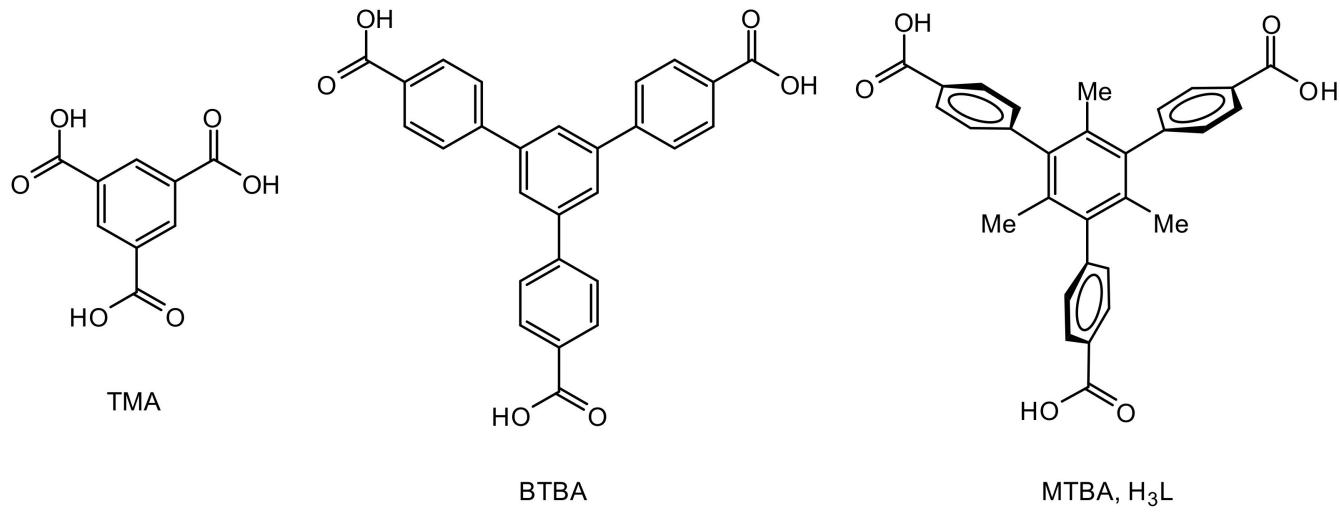

Figure 1. Tritopic linkers used in the construction of metal-organic frameworks (MOFs).

Coordination geometry flexibility and high coordination numbers make lanthanide-based MOFs a promising class of porous materials with useful properties such as luminescence, thermal stability, magnetism, and catalytic behavior [26,33-36]. MTBA possesses intrinsic fluorescence. Even though a number of complexes with MTBA as a linker have been documented in the literature [28,30,31,37-41], lanthanide(III)-based MOFs with this tritopic ligand have not been reported as yet.

Herein, we report on the synthesis and characterization of a series of lanthanide-based MOFs of general formula $\left[\mathrm{LnL}\left(\mathrm{H}_{2} \mathrm{O}\right)_{2}\right]_{\mathrm{n}}$ where $\mathrm{Ln}=\mathrm{La}(\mathbf{1}), \mathrm{Ce}(2), \mathrm{Nd}(3), \mathrm{Eu}(4), \mathrm{Gd}(5), \mathrm{Dy}(6)$, and Ho (7), and 1,3,5-tris(4-carboxyphenyl)-2,4,6-trimethylbenzene $\left(\mathrm{H}_{3} \mathrm{~L}\right)$ is the linker. The aim of this work was the synthesis of new MOFs with the tribasic tricarboxylate $\mathrm{H}_{3} \mathrm{~L}$ ligand (MTBA) and the investigation of their physicochemical properties, crystal structures, thermal, and luminescence properties. Additionally, for these new Ln-MOFs, their potential catalytic activity was established for O-acylation reactions.

\section{Results and Discussion}

The linker precursor 1,3,5-tris(4-carboxyphenyl)-2,4,6-trimethylbenzene $\left(\mathrm{H}_{3} \mathrm{~L}\right)$, also called mesitylenetribenzoic acid (MTBA), previously reported by Bajpai et al. [30], was prepared in moderate yield (50\%) as described in the Supplementary Materials. The structure and purity of $\mathrm{H}_{3} \mathrm{~L}$ were confirmed by IR and NMR spectroscopy. The lanthanide complexes 1-7 were prepared by the solvothermal reaction of $\mathrm{H}_{3} \mathrm{~L}$ with $\mathrm{Ln}\left(\mathrm{NO}_{3}\right)_{3} \cdot 6 \mathrm{H}_{2} \mathrm{O}$ [ $\mathrm{Ln}=\mathrm{La} ; \mathrm{Ce} ; \mathrm{Nd} ; \mathrm{Eu} ; \mathrm{Gd}$; Dy; Ho]. The optical microscopy images (Figure S1) of all lanthanide complexes are given in the SM. To optimize the reaction conditions, different solvents and mixtures were used (DMF, DMSO, $\mathrm{H}_{2} \mathrm{O}$, and ethanol). In addition, different reaction temperatures and times were used in order to obtain crystalline products suitable for x-ray diffraction. The optimal conditions were found to be an $\mathrm{EtOH} / \mathrm{H}_{2} \mathrm{O} / \mathrm{DMF}$ solvent mixture, a reaction temperature of $80^{\circ} \mathrm{C}$, and a reaction time of one to five days (see Table S1, in the SM).

The chemical robustness of the Ln-MOF 3 was exemplarily checked by immersing in a $2 \mathrm{~mol} / \mathrm{L}$ solution of $\mathrm{NaOH}$ and $\mathrm{HNO}_{3}$, respectively, for one day. Compound 3 (10 mg) was suspended in $2 \mathrm{~mL}$ of acidic/basic solution for $24 \mathrm{~h}$, filtered off, washed, dried in air, and investigated by PXRD analysis. As can be seen in Figure S14 (SM), compound 3 decomposed in $2 \mathrm{~mol} / \mathrm{L}$ of aqueous acid or base. The Ln-MOFs 1-7 were, however, stable in air and solvent (ethanol, DMF, $\mathrm{H}_{2} \mathrm{O}$-mother liquor) for more than one week. Powder x-ray diffraction patterns recorded after two weeks showed that these compounds are unaffected by the solvents. 


\subsection{Structural Characterization}

The results of single-crystal x-ray diffraction studies are shown in Figure 2; Figure 3. It should be noted that the three complexes described here exhibited similar structural features, being constructed in the same way. Moreover, compounds $\mathbf{1}$ and $\mathbf{2}$ were isostructural, therefore only the structure of compound $\left[\mathrm{LaL}\left(\mathrm{H}_{2} \mathrm{O}\right)_{2}\right]_{\mathrm{n}}$ (1) is described below in detail (Figure 2). Complex $\mathbf{1}$ crystallizes in the orthorhombic space group Pnna. As shown in Figure 2a, the asymmetric unit comprises a La atom in a special position on a two-fold axis, half of the deprotonated $\mathrm{L}^{3-}$ ligand, and one coordinated water molecule. The $\mathrm{L}^{3-}$ tricarboxylate linker acts as an eight-dentate ligand, bridging and chelating toward five La atoms. Two of the carboxylate groups are coordinated in $\mu_{2}-\mathrm{K}^{3} \mathrm{O}, \mathrm{O}^{\prime}: O$ tridentate-bridging mode, while the third group exhibits a $\mathrm{K}^{2} \mathrm{O}, \mathrm{O}^{\prime}$ bidentate-chelating function. The La atom is coordinated by ten oxygen atoms in a distorted square antiprism geometry (Figure 2a polyhedron). The La-O bond distances vary in the range 2.503(7)-3.017 $\AA$ and $2.461(4)-3.177(4) \AA$ for $\left[\mathrm{LaL}\left(\mathrm{H}_{2} \mathrm{O}\right)_{2}\right]_{\mathrm{n}}(\mathbf{1})$ and $\left[\mathrm{CeL}\left(\mathrm{H}_{2} \mathrm{O}\right)_{2}\right]_{n}(2)$, respectively. In the crystal, the asymmetric units are assembled to form a three-dimensional coordination network (Figure $2 b-d$ ). It can be described as formed by infinite linear arrays of La atoms bridged by $\mu_{2}-\mathrm{K}^{3} \mathrm{O}, \mathrm{O}^{\prime}: \mathrm{O}$ tridentate-bridging/chelating carboxylate groups along the $a$ axis. These linear chains are further interconnected via tripodal spacers $\mathrm{L}^{3-}$. Within the linear chain, the two neighboring La atoms are separated at 4.690(4) $\AA$ across the tricarboxylate spacers at 16.356(4) $\AA$. The network structure forms large rectangular channels of $17.5 \times 12.7 \AA$ (taking into account the van-der-Waals surfaces) directed along the $b$ axis (Figure 2c), indicating the potential porosity of this compound. The solvent-accessible volume of the channels is equal to $2060 \AA^{3} /$ unit cell, $^{2}$ which constitutes $48 \%$ of the unit cell volume.

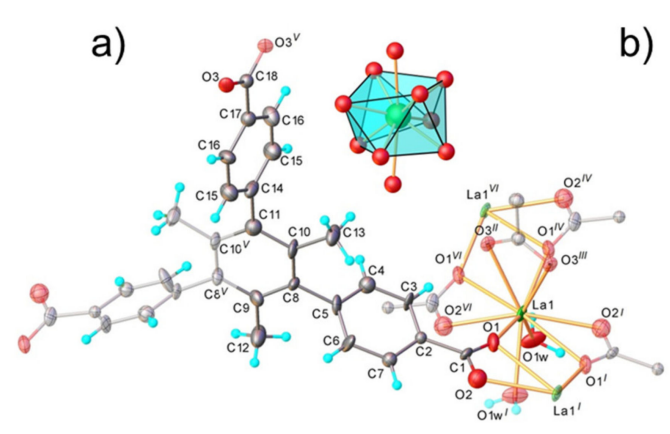

C)

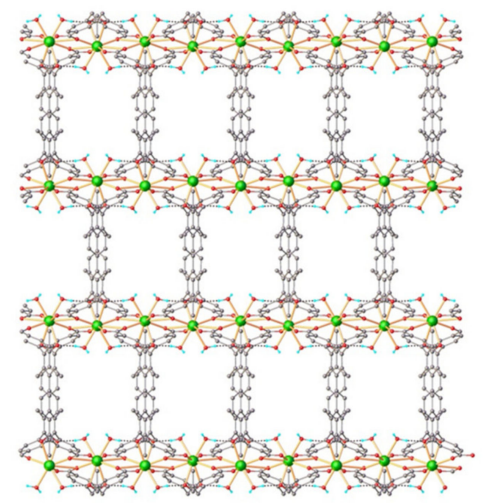

b)

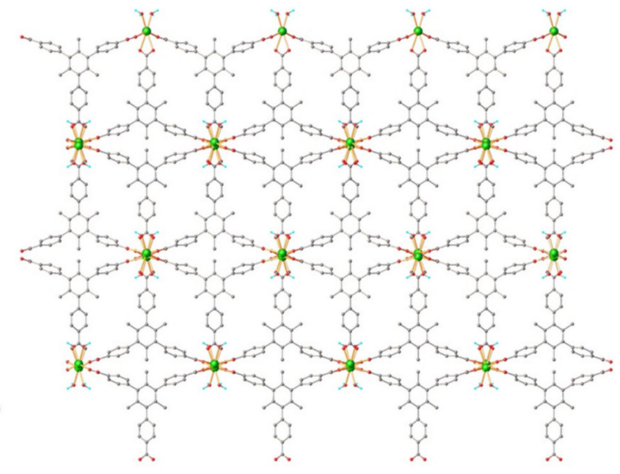

d)

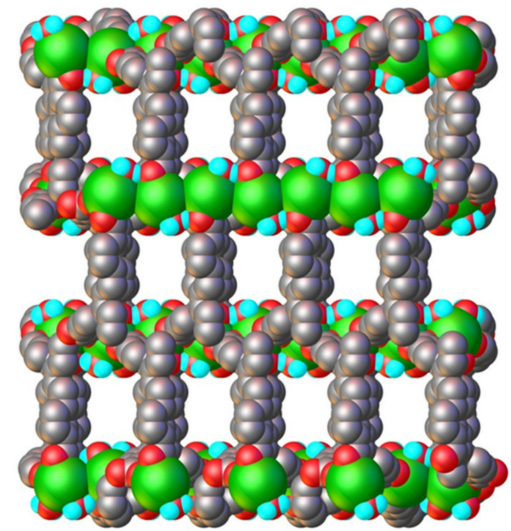

Figure 2. Crystal structure of compound $\left[\mathrm{LaL}\left(\mathrm{H}_{2} \mathrm{O}\right)_{2}\right]_{n}$ (1). Extended view of the asymmetric part and coordination environment around La in $\mathbf{1}$ along with the atom labelling scheme and thermal ellipsoids at the $40 \%$ probability level. Symmetry generated fragments are drawn with $50 \%$ transparency (a). Crystal structure packing viewed along the $a$ axis (b). View of the crystal structure showing formation of the channels along the $b$ axis (c). Space filling representation for (d). Symmetry codes: $\mathrm{I}=1-x$, $1-y, 1-z ; \mathrm{II}=1.5-x, 0.5+y, 0.5-z ; \mathrm{III}=x, 0.5-y, 0.5-z ; \mathrm{IV}=2-x, 1-y, 1-z ; \mathrm{V}=1.5-x,-y, z$; $0.5+x, y, 1-z$. 


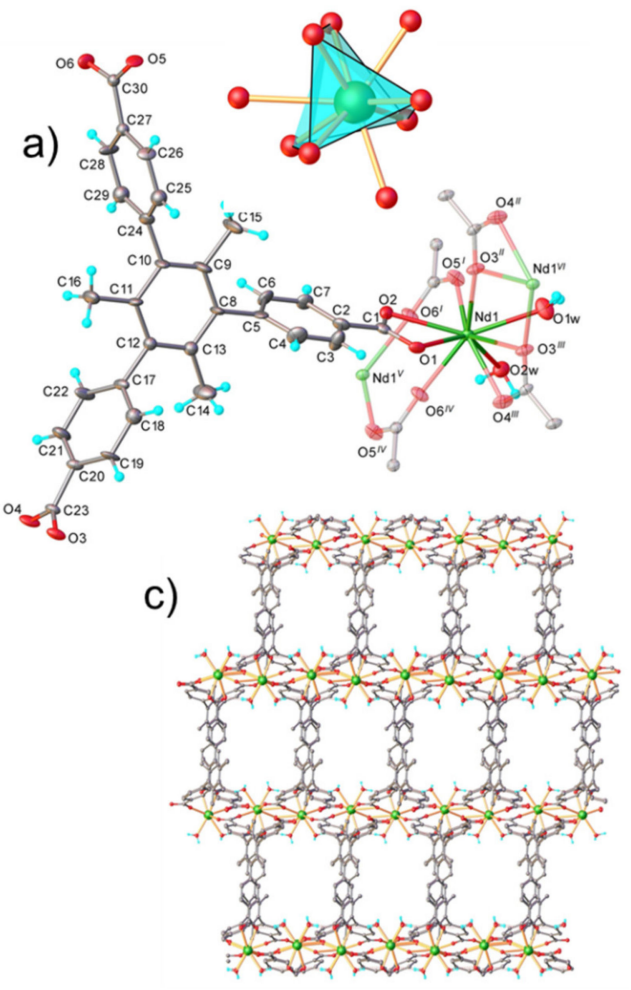

b)

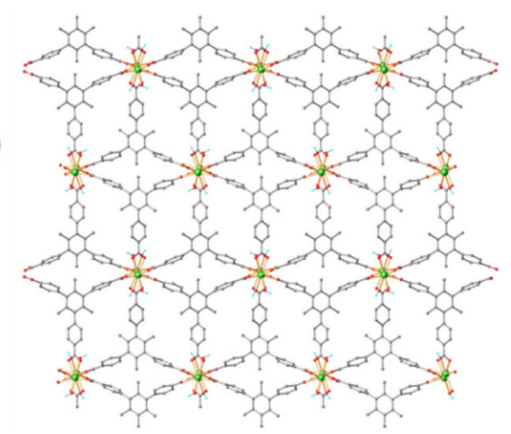

d)

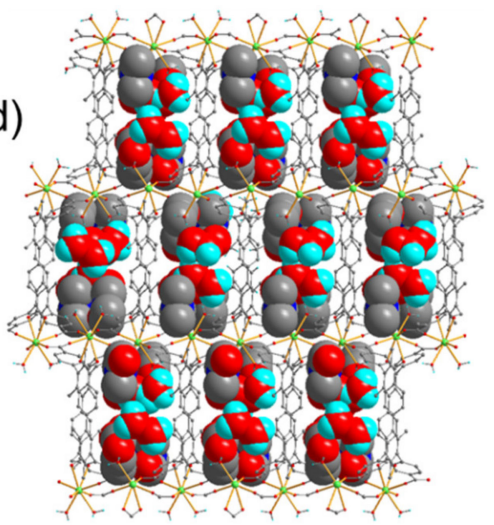

Figure 3. Crystal structure of $\left[\mathrm{NdL}\left(\mathrm{H}_{2} \mathrm{O}\right)_{2}\right] \cdot 1.33 \mathrm{DMF} \cdot 2 \mathrm{H}_{2} \mathrm{O}$ (3). Extended view of the asymmetric part and coordination environment around the $\mathrm{Nd}$ atom in 3 along with the atom labeling scheme and thermal ellipsoids at the $40 \%$ probability level. Symmetry generated fragments are drawn with 50\% transparency (a). Crystal structure packing viewed along the $a$ axis (b). View of the crystal structure showing the formation of the channels along the $b$ axis (c); with space filling representation of the co-crystallized DMF and $\mathrm{H}_{2} \mathrm{O}$ solvent molecules (d). Symmetry codes: $\mathrm{I}=0.5+x, 1.5-y, 0.5+z$; $\mathrm{II}=0.5-x, 0.5+y, 1.5-z ; \mathrm{III} 0.5+x, 0.5-y, 0.5+z ; \mathrm{IV}=0.5-x,-0.5+y, 1.5-z ; \mathrm{V}=1-x, 1-y$, $2-z ; \mathrm{VI}-x, 1-y, 2-z$.

Compared with compounds $\mathbf{1}$ and $\mathbf{2}$, the x-ray diffraction study for $\mathbf{3}$ yielded very similar unit cell dimensions. Nevertheless, compound 3 crystallized in the monoclinic space group $\mathrm{P} 21 / \mathrm{n}$, having a $\beta$ angle of $93.098(18)^{\circ}$. The crystal structure is formed by the $\left[\mathrm{NdL}\left(\mathrm{H}_{2} \mathrm{O}\right)_{2}\right]_{n}$ coordination polymer and solvate molecules of $\mathrm{H}_{2} \mathrm{O}$ and DMF in a 1:2:1.33 stoichiometric ratio. A view of the asymmetric unit is shown in Figure 3a. The coordination environment of Nd comprises nine oxygen atoms, seven of which come from five carboxylate groups and two from coordinated water molecules. The coordination polyhedron was different compared to compounds 1 and 2: this can be characterized as a tricapped trigonal prism (Figure 3a polyhedron). The $\mathrm{Nd}-\mathrm{O}$ bond distances vary in the range of 2.464(6)-2.947(6) $\AA$. As shown in Figure 3 , the three-dimensional network in $\mathbf{3}$ closely resembles that found for $\mathbf{1}$ and 2 (cf. Figure $2 b, c$ ). In the structure of 3 , the positions of the $\mathrm{H}_{2} \mathrm{O}$ and DMF solvent molecules could be easily determined from Fourier maps and refined. A view of the crystal structure along the $b$ axis showing the channels accommodating the solvent molecules is depicted in Figure 3d.

\subsection{Infrared Spectroscopy Attenuated Total Reflectance (ATR)}

For all synthesized lanthanide metal-organic frameworks, the ATR spectra were quite similar and are given in the Supplementary Materials (Figures S2-S9). The IR spectra showed strong characteristic adsorptions in the $1610-1520 \mathrm{~cm}^{-1}$ and $1420-1370 \mathrm{~cm}^{-1}$ interval, assigned to the symmetric/asymmetric $\mathrm{COO}^{-}$vibrations of the ligand carboxylate groups. The broad bands between 3600 and $3200 \mathrm{~cm}^{-1} \mathrm{can}$ be attributed to the hydrogen bonded $v \mathrm{OH}$ groups from adsorbed water. 


\subsection{Powder X-ray Diffraction}

Powder X-ray diffraction (PXRD) reveals information about the crystallinity and crystalline phase purity of the material. The PXRD patterns were recorded after the compounds had been filtered, air-dried, and exposed to air for at least a few days (Figures S10-S20). The patterns recorded for all compounds were in good agreement with each other, as can be seen in Figure S20. The simulation versus experimental patterns for 1-3 are represented in Figures S11-S13.

\subsection{Thermogravimetric Analysis (TG/DTG)}

Thermal stability and the pathways of thermal decomposition of all complexes were investigated by means of the TG-DTG (nitrogen) methods (see Figures S21-S28). The newly synthesized Ln-MOFs were found to have high thermal stability compared with the ligand. For compounds $\mathbf{1}$ and $\mathbf{2}$, the first weight loss of $3-4 \%$ corresponded to the loss of water molecules. Above around $480{ }^{\circ} \mathrm{C}$, the decomposition process of the framework and organic ligand takes place. The TG trace of the as-synthesized 3 showed a mass loss of $\sim 11 \%$ up to $220^{\circ} \mathrm{C}$, which can be attributed to the loss of water molecules and part of the DMF molecules (theor. $21 \%$ for water and DMF). When compound 3 was analyzed after activation and gas sorption measurements, no mass loss up to $480^{\circ} \mathrm{C}$ was observed, which is evidence of successful solvent removal. During heating of 5, the desolvation process took place in three steps. The first weight loss $(\sim 5 \%)$ found in the temperature range of $40-220{ }^{\circ} \mathrm{C}$ is associated with the loss of solvent molecules (calc. 4.5\%). Further heating caused the decomposition of the organic ligand. The thermal decomposition curves of compounds 4, 6, and 7 showed a similar behavior and high thermal stability at about $500{ }^{\circ} \mathrm{C}$, as presented in the SM. It is worth pointing out that the MOFs presented here have a high thermal stability that is similar to other lanthanide metal organic frameworks [42].

\subsection{Sorption Properties}

In order to assess the porous nature of compounds 1-7, the nitrogen adsorption-desorption isotherms at $-196{ }^{\circ} \mathrm{C}$ were recorded. Prior to measurement, the samples were outgassed for $4 \mathrm{~h}$ under a high vacuum $\left(2.7 \times 10^{-2} \mathrm{mbar}\right)$ at $80^{\circ} \mathrm{C}$. The compounds exhibited permanent porosity with BET surface areas from 110 to $470 \mathrm{~cm}^{2} / \mathrm{g}$, and total pore volumes between 0.1 to $0.2 \mathrm{~cm}^{3} / \mathrm{g}$ (Table 1 ). The obtained nitrogen isotherms are shown in Figures S30-S36 in the Supplementary Materials.

Table 1. BET surface area and total pore volume for Ln-MOFs compound.

\begin{tabular}{|c|c|c|}
\hline Ln-MOFs-Activated Compounds & BET Surface Area $\left[\mathrm{m}^{2} / \mathrm{g}\right]$ & $\begin{array}{l}\text { Total Pore Volume } \\
{\left[\mathrm{cm}^{3} / \mathrm{g}\right]}\end{array}$ \\
\hline$\left[\mathrm{LaL}\left(\mathrm{H}_{2} \mathrm{O}\right)_{2}\right]_{\mathrm{n}}$-act $(\mathbf{1}$-act $)$ & $405 / 395 *$ & 0.19 \\
\hline$\left[\mathrm{CeL}\left(\mathrm{H}_{2} \mathrm{O}\right)_{2}\right]_{\text {n-act }}(2-\mathrm{act})$ & $467 / 460 *$ & 0.20 \\
\hline$\left[\mathrm{NdL}\left(\mathrm{H}_{2} \mathrm{O}\right)_{2}\right]_{\text {n-act }}(3-\mathrm{act})$ & $426 / 404 *$ & 0.20 \\
\hline$\left[\mathrm{EuL}\left(\mathrm{H}_{2} \mathrm{O}\right)_{2}\right]_{\text {n-act }}(4-\mathrm{act})$ & 114 & 0.08 \\
\hline$\left[\mathrm{GdL}\left(\mathrm{H}_{2} \mathrm{O}\right)_{2}\right]_{\text {n-act }}(5-\mathrm{act})$ & 348 & 0.18 \\
\hline$\left[\mathrm{DyL}\left(\mathrm{H}_{2} \mathrm{O}\right)_{2}\right]_{\text {n_act }}(6-\mathrm{act})$ & 202 (Figure S35a) & 0.16 \\
\hline$\left[\mathrm{DyL}\left(\mathrm{H}_{2} \mathrm{O}\right)_{2}\right]_{\mathrm{n}}$-act $(6-\mathrm{act})$ & 298 (Figure S35b) & 0.16 \\
\hline$\left[\mathrm{HoL}\left(\mathrm{H}_{2} \mathrm{O}\right)_{2}\right]_{\text {n-act }}(7-\mathrm{act})$ & 286 & 0.15 \\
\hline
\end{tabular}

* The same compound, second measuring, without exposing to air. The experimental error for a BET surface area is about $5-10 \%$.

The structurally authenticated compounds 1-3 exhibited adsorption isotherm branches as a composite of Types I and II with a H4 hysteresis loop. The pronounced uptake at low $\mathrm{p} / \mathrm{p}_{0}$ is associated with the filling of micropores. H4 loops are often found with aggregated crystals or micro-mesoporous materials $[43,44]$. Of note, structurally similar compounds 1-3 (see Figure 4) also exhibited rather similar surface areas between $400-460 \mathrm{~m}^{2} / \mathrm{g}$ and a total pore volume of $0.19-0.20 \mathrm{~cm}^{3} / \mathrm{g}$. In a repeated adsorption/desorption cycle, the surface area remains unchanged within the experimental error [44]. 


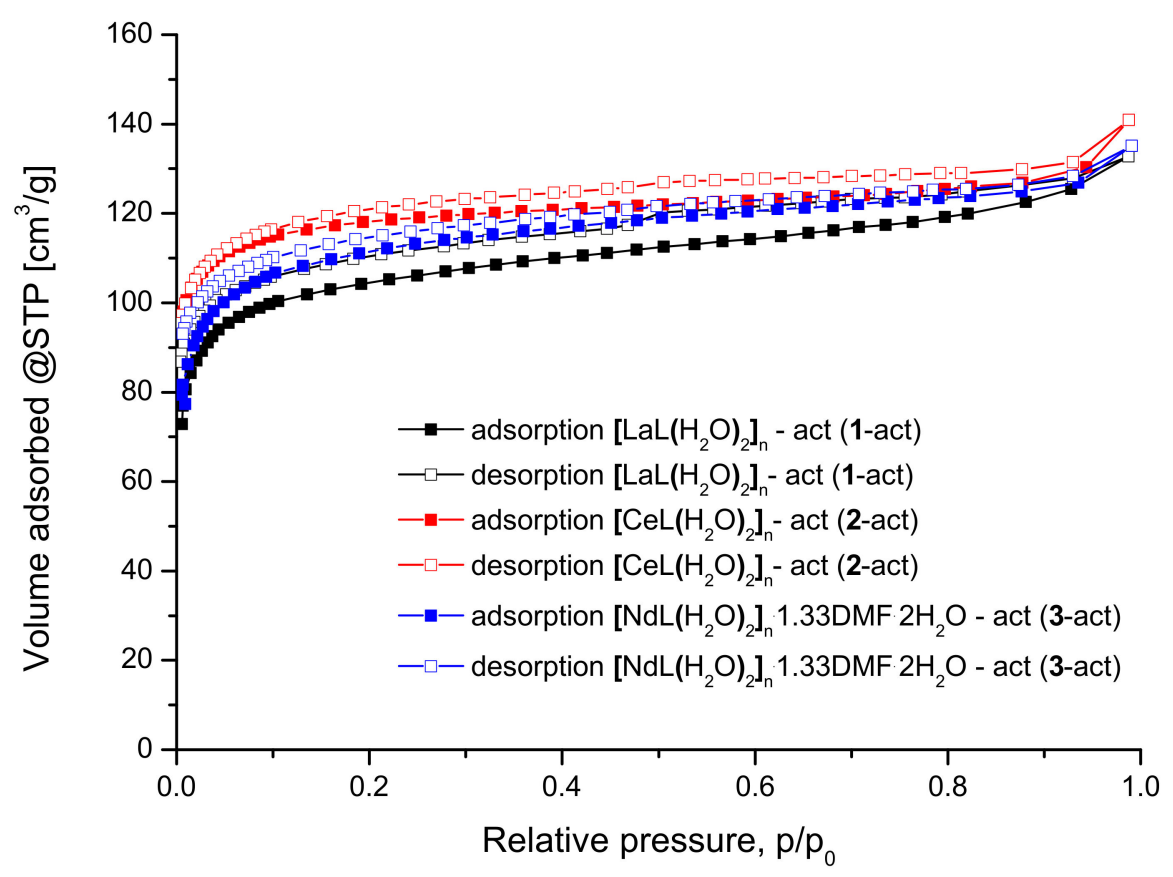

Figure 4. $\mathrm{N}_{2}$ sorption isotherms of the activated compounds of 1-3 at $77 \mathrm{~K}$. Closed and open symbols refer to adsorption and desorption, respectively.

Compounds 4-7 still feature adsorption isotherm branches that can be viewed as a composite of Types I and II. However, there is essentially no desorption until $\mathrm{p} / \mathrm{p}_{0}<\sim 0.1-0.15$ for 4-6 (for $\mathbf{6}$ after the second adsorption run). For 7 , the desorption starts around $\mathrm{p} / \mathrm{p}_{0}<\sim 0.3$. For $4-7$, about $80 \%$ of the adsorbed $\mathrm{N}_{2}$ is still retained at a very low $\mathrm{p} / \mathrm{p}_{0}$ of $\sim 0.01$. There is a final steep desorption branch at $\mathrm{p} / \mathrm{p}_{0}$ of $\sim 0.01$ for these remaining $80 \%$. Such a very steep desorption branch is also a characteristic feature of H2(a) hysteresis loops and can be attributed either to pore-blocking/percolation in a narrow range of pore necks or to cavitation-induced evaporation [44].

A similar sorption behavior with broad isotherms and steep desorption steps at low pressures was frequently observed for $\mathrm{H}_{2}$ and $\mathrm{CH}_{4}$ adsorption in IFP MOFs [45-48] and in supramolecular hydrogen-bonded imidazolate frameworks (HIFs) [49,50] with gate effects (IFP = imidazolate framework Potsdam), in part also for $\mathrm{CO}_{2}$ adsorption in IFPs [47,51]. Such a broad desorption behavior is rarely observed in microporous MOFs and only observed for MOFs with flexible substituents. The structurally authenticated IFPs possess very small, less than $1 \AA$, pore aperture windows to the cavities and flexible ethoxy or methoxy groups form the pore aperture windows [47,48]. For $\mathrm{H}_{2}$ sorption at $77 \mathrm{~K} \mathrm{IFP-7} \mathrm{[48],}$ IFP-8 [45,46] and IFP-9 [48] exhibits an open-loop hysteresis due to almost irreversible adsorption at higher relative pressure. Although $\mathrm{H}_{2}$ is a small molecule with a kinetic diameter of only $2.89 \AA$ at $77 \mathrm{~K}$, the sorption isotherms can deviate from ideal equilibrium experiments as pronounced kinetic effects occur because of the small channel size and the gate effect. In IFP-7, $98 \%$ of the adsorbed $\mathrm{H}_{2}$ is trapped in the framework when the pressure is reduced from $840 \mathrm{mmHg}$ to $100 \mathrm{mmHg}$, and $70 \%$ of the adsorbed $\mathrm{H}_{2}$ remains when the pressure is further reduced to $7 \mathrm{mmHg}$ [48]. In IFP-8, $98 \%$ of the adsorbed $\mathrm{H}_{2}$ is trapped in the framework when the pressure is reduced from $760 \mathrm{mmHg}$ ( 1 bar) to $114 \mathrm{mmHg}$ (0.15 bar) [45].

\subsection{Luminescence}

It is known that lanthanides often exhibit luminescence properties $[1,16,52]$. In order to study the luminescence properties of the synthesized frameworks, the fluorescence spectra of Ln-MOFs $(\mathbf{1}, \mathbf{2}, \mathbf{3}$, and 4 ) as well as ligand $\mathrm{H}_{3} \mathrm{~L}$ were recorded in solid state (powder) at room temperature. It was found that $\mathrm{H}_{3} \mathrm{~L}$ displays an emission maximum at $437 \mathrm{~nm}$ upon excitation at $\lambda=365 \mathrm{~nm}$. Similar emissions 
in the UV region were observed for frameworks 1, 2, and 3 (Figure 5), which can be attributed to the organic ligand. In the case of the Eu based framework 4, besides the weak blue emission of the ligand, typical red emissions attributed to the $\mathrm{Eu}^{3+}$ ion were observed. The characteristic sharp emissions at $\lambda=561 \mathrm{~nm}$ (very weak, $\left.{ }^{5} \mathrm{D}_{0} \rightarrow{ }^{7} \mathrm{~F}_{0}\right), \lambda=589 \mathrm{~nm}$ (medium, $\left.{ }^{5} \mathrm{D}_{0} \rightarrow{ }^{7} \mathrm{~F}_{1}\right), \lambda=611 \mathrm{~nm}$ (very strong, ${ }^{5} \mathrm{D}_{0} \rightarrow{ }^{7} \mathrm{~F}_{2}$ ), $\lambda=616 \mathrm{~nm}$ (very weak, ${ }^{5} \mathrm{D}_{0} \rightarrow{ }^{7} \mathrm{~F}_{3}$ ), and $\lambda=697 \mathrm{~nm}$ (very weak, ${ }^{5} \mathrm{D}_{0} \rightarrow{ }^{7} \mathrm{~F}_{4}$ ) were in good correlation with the data reported in the literature [53-55]. The red emissions of framework 4 were confirmed through fluorescence microscopy by irradiating at $\lambda=365 \mathrm{~nm}$, as can be seen in the SM, Figure S37.

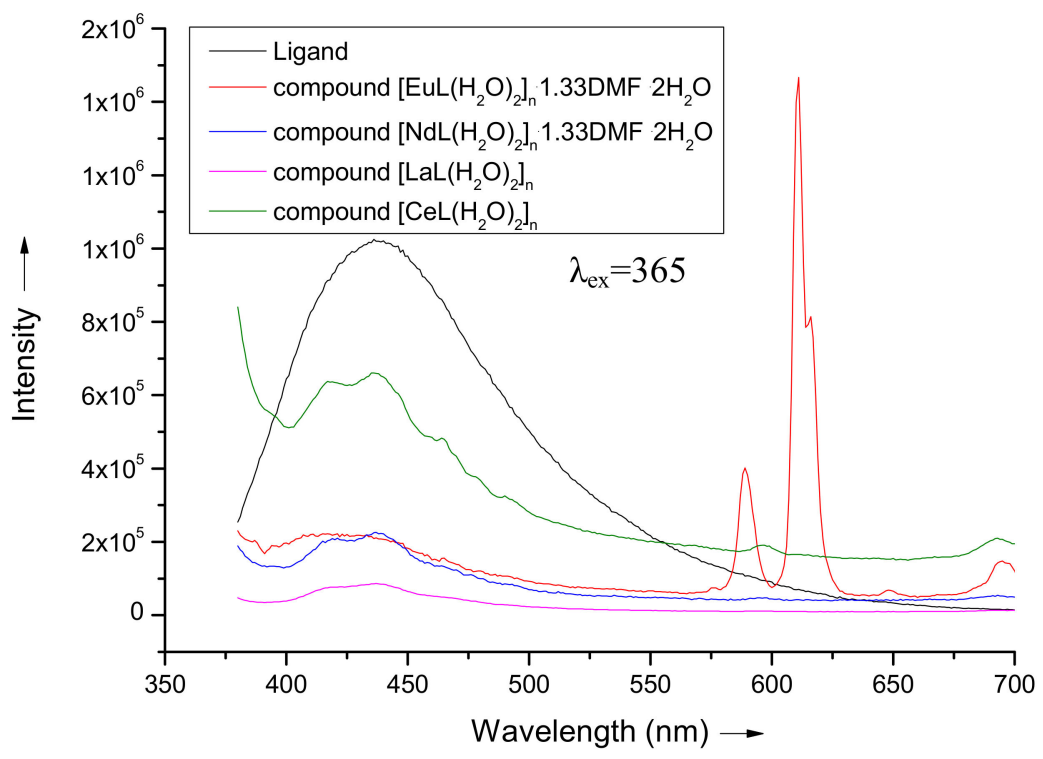

Figure 5. Emission spectra of ligand and lanthanide MOF 1-4 obtained under excitation at $365 \mathrm{~nm}$.

\subsection{Catalytic Activity}

Two Ln-MOFs (1 and 3) were investigated in O-acylation reactions to explore their Lewis-acidic properties. Despite the large number of reported O-, N-, S- acylation processes [56,57], in the last decade, the involvement of MOFs in heterogeneous catalysis has greatly increased [58,59]. The advantages of MOF materials are solid-state catalytic activity, together with the robustness of their structure, allowing facile separation after the catalytic process $[56,59,60]$.

In the present work, the conversion of 2-naphthol to 2-naphthyl acetate by the reaction with $\left(\mathrm{CH}_{3} \mathrm{COO}\right)_{2} \mathrm{O}$ in the presence of lanthanide-MOFs as catalysts (Scheme 1) was investigated. The reactions were carried out with 1.5 equivalents of acetic anhydride at room temperature in the presence of $1 \mathrm{~mol} \%$ of catalysts and chloroform as the solvent for $24 \mathrm{~h}$.

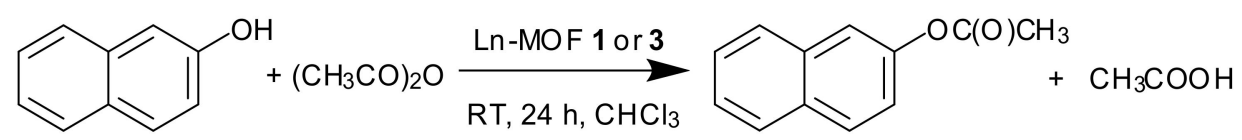

Scheme 1. Acylation of 2-naphthol with acetic anhydride in the presence of $\mathbf{1}$ or $\mathbf{3}$ as the catalyst.

In the control experiment, in the absence of the catalyst, the yield of the acylated product was lower than $10 \%$. Before each catalytic experiment, the catalyst was activated by washing several times with chloroform and then drying in an oven at $80^{\circ} \mathrm{C}$ for $20 \mathrm{~h}$. The catalytic activity of the lanthanide-based MOFs was tested in multiple run experiments (see Table 2). When the reactions were catalyzed by 1 ( $1 \mathrm{~mol} \%)$, the yield was $88 \%$. When the catalyst used was 3 , the yields were 98\% (run 1), 96\% (run 2), and 92\% (run 3) (see Table 2, Entry 1-4). The spectral data of the isolated yellowish powders of 2-naphthylacetate were in full agreement with the authentic samples (Mp, NMR, 
see Figure S29, SM) [61]. The results were expressed as the average of at least two independent measurements performed for each sample.

Table 2. Acylation of $\mathrm{O}-$ substrates with $\mathrm{Ac}_{2} \mathrm{O}$ in the presence of $\mathbf{1}$ and $\mathbf{3}$ as catalysts.

\begin{tabular}{cccccc}
\hline Entry & Substrate & Conversion * & Time & Catalyst & $\begin{array}{c}\text { Run } \\
\text { Number }\end{array}$ \\
\hline 1 & 2-naphthol & 88 & 24 & $\mathbf{1}$ & 1 \\
2 & 2-naphthol & 98 & 24 & $\mathbf{3}$ & 1 \\
3 & 2-naphthol & 96 & 24 & $\mathbf{3}$ & 2 \\
4 & 2-naphthol & 92 & 24 & $\mathbf{3}$ & 3 \\
5 & 2-naphthol & 65 & 5 & $\mathbf{3}$ & 1 \\
& & 65 & 24 & - & 2 \\
$6 * *$ & 2-naphthol & 80 & 24 & $\mathbf{3}$ & 1 \\
& & 72 & 24 & $\mathbf{3}$ & 2 \\
\hline
\end{tabular}

* Every experiment was performed at least in duplicate; ${ }^{* *}$ The catalyst is dried in air.

Critically important for MOF catalysts is the framework stability during catalysis. For compound 3, this was tested over three runs and the results showed a stable catalytic activity. In addition, after the first and the third run, the catalyst was analyzed for crystallinity by PXRD. The results indicate that the compound was only stable over one run, but had significantly deteriorated after the third run (Figure S15, SM). Moreover, two catalytic reactions were carried out with the activated and non-activated catalyst. It is clear that without activating the catalyst, the yield is much lower (see Table 2, entry 6).

In order to prove the heterogeneity of the catalytic process, a room temperature filtration test was performed. The catalyst was removed from the reaction mixture after $5 \mathrm{~h}$ using a glass frit funnel. The results show that after removing the catalyst, the reaction did not proceed further, indicating that no catalytically active materials remained in the filtrate (Table 2, entry 5).

\section{Material and Methods}

All chemicals were purchased from commercial suppliers and used as received. The Nuclear Magnetic Resonance (NMR) spectra were recorded on a BRUKER AVANCE III 400 (Bruker BioSpin Rheinstetten, Germany) instrument operating at 400.1 and $100.6 \mathrm{MHz}$ for ${ }^{1} \mathrm{H}$ and ${ }^{13} \mathrm{C}$ nuclei, respectively. Carbon, Hydrogen, Nitrogen elemental analysis was performed on a vario Micro cube CHNS analyzer from Elementar Analysensysteme $\mathrm{GmbH}$, Germany. Infrared (IR) spectra were recorded on a BRUKER VERTEX 70 (Bruker Optik GmbH, Ettlingen, Germany) FTIR spectrometer with the measurements performed in ATR (attenuated total reflectance) Golden Gate ${ }^{\circledR}$ mode in the $600-4000 \mathrm{~cm}^{-1}$ range at room temperature with a resolution of $4 \mathrm{~cm}^{-1}$ and accumulation of 64 scans. Powder x-ray diffraction (PXRD) patterns were collected on a Bruker AXS D2 Phaser powder diffractometer (Bruker AXS $\mathrm{GmbH}$, Karlsruhe, Germany) equipped with a flat silicon, low background sample holder using $\mathrm{Cu}-\mathrm{K} \alpha$ radiation $\left(\lambda=1.5418 \AA\right.$ ) with a scan speed of $0.2 \mathrm{~s} /$ step and a step size of $0.02^{\circ}(2 \theta)$ at $290 \mathrm{~K}$ in the range of $2 \theta=5-40^{\circ}$. Simulated PXRD patterns were calculated with the CCDC Mercury 3.1 program (Cambridge, UK) using the single-crystal data of the compounds. A STA 449F1 JUPITER (Netzsch, $\mathrm{GmbH}$, Selb, Germany) thermal analyzer from Netzsch was employed for the thermogravimetric (TG) measurements at a heating rate of $5^{\circ} \mathrm{C} \mathrm{min}^{-1}$ between 30 and $700{ }^{\circ} \mathrm{C}$. The data were processed with the NETZSCH PROTEUS 4.2 software (Netzsch, GmbH, Selb, Germany). Nitrogen sorption experiments (up to 1 bar) for the BET surface area and porosity determination were measured with a Quantachrome NOVA 4200e (Quantachrome GmbH \& Co. KG, Odelzhausen, Germany) at 77 K. About 20 to $40 \mathrm{mg}$ of freshly synthesized samples were weighed before and after the degassing procedure to confirm the evacuation of the solvent. The fluorescence microscopy imaging was performed on a Leica DMI 3000 B (Leica Microsystems, Germany) microscope equipped with "A" and "GFP" filter cubes, with UV $(365 \mathrm{~nm})$ and green excitation $(470 \mathrm{~nm})$, respectively. The solid-state fluorescent study was conducted 
at room temperature on a Horiba Fluoromax-4 fluorescence spectroscopy instrument (HORIBA Jobin Yvon GmbH, Bensheim, Germany).

\subsection{Synthesis of the Ligand 1,3,5-tris(4-carboxyphenyl)-2,4,6-trimethylbenzene $\left(\mathrm{H}_{3} \mathrm{~L}\right)$}

The linker $\mathrm{H}_{3} \mathrm{~L}$ was prepared according to a procedure described in the literature [30] and its structure and purity were confirmed by NMR and IR spectroscopy.

${ }^{1} \mathrm{H}$ NMR (DMSO-d6, $\left.400.1 \mathrm{MHz}, \mathrm{ppm}\right): \delta=12.9(\mathrm{~s}, 3 \mathrm{H}) ; 8.04\left(\mathrm{~d},{ }^{3} \mathrm{~J}_{\mathrm{H}, \mathrm{H}}=8.04 \mathrm{~Hz}, 6 \mathrm{H}\right) ; 7.35\left(\mathrm{~d},{ }^{3} \mathrm{~J}_{\mathrm{H}, \mathrm{H}}=\right.$ $8.04 \mathrm{~Hz}, 6 \mathrm{H}) ; 1.62$ (s, 9H). ${ }^{13} \mathrm{C}$ NMR (DMSO-d6, $\left.100.6 \mathrm{MHz}, \mathrm{ppm}\right): \delta=167.6 ; 146.3 ; 139.2 ; 132.3 ; 130.1$; 129.9; 129.8; 19.6. IR (ATR): $v\left(\mathrm{~cm}^{-1}\right)=640.33(\mathrm{~m}) ; 661.54(\mathrm{w}) ; 682.76(\mathrm{w}) ; 715.50(\mathrm{~m}) ; 759.91(\mathrm{~s}) ; 796.55$ (m); 864.06 (s); 960.49 (w); 1018.35 (m): 1043.42 (w); 1060.78 (w); 1097.43 (m); 1143.72 (vw); 1178.43 (w); 1253.65 (w); 1278.73 (w); 1305.73 (m); 1411.81 (vs); 1519.81 (s); 1583.46 (vs); 1664.47 (s); 1820.69 (vw); $1944.13(\mathrm{vw}) ; 2279.72(\mathrm{vw}) ; 2561.31(\mathrm{vw}) ; 2750.32(\mathrm{vw}) ; 2923.90(\mathrm{w}) ; 3355.93(\mathrm{w}) ; 3512.16(\mathrm{w})$; $3807.25(\mathrm{vw})$.

\subsection{Typical Synthesis of Ln-MOFs Where $L n=L a(1), C e(2), N d(3), E u(4), G d(5), D y(6), H o(7)$}

All complexes were prepared in the same manner using the following procedure. To a solution of $\mathrm{H}_{3} \mathrm{~L}\left(0.01 \mathrm{~g}, 0.02 \mathrm{mmol}\right.$ ) in dimethylformamide (DMF) (except $\mathrm{La}\left(\mathrm{NO}_{3}\right)_{3} \cdot 6 \mathrm{H}_{2} \mathrm{O}$ and $\mathrm{Ce}\left(\mathrm{NO}_{3}\right)_{3} \cdot 6 \mathrm{H}_{2} \mathrm{O}$ where ethanol was used) in a $20 \mathrm{~mL}$ culture tube was added $\mathrm{Ln}\left(\mathrm{NO}_{3}\right)_{3} \cdot 6 \mathrm{H}_{2} \mathrm{O}(\sim 0.036 \mathrm{~g}, 0.08 \mathrm{mmol})$ dissolved in ethanol/water at room temperature (see Table S1, Supplementary Materials (SM) for the volumes and solvents used). The tube with a clear solution was kept under static conditions for 1-5 days at $80{ }^{\circ} \mathrm{C}$ (reaction times are detailed in Table S1, SM). After cooling, the crystalline product was collected by centrifugation and washed with DMF and ethanol. Finally, the crystals were dried at room temperature. Specific conditions for each Ln-MOF are given in section S1, SM.

[LaL $\left.\left(\mathrm{H}_{2} \mathrm{O}\right)_{2}\right]_{\mathrm{n}}$ (1): Yield 62\%; Elemental analysis calcd. (\%) for $\mathrm{C}_{30} \mathrm{H}_{25} \mathrm{LaO}_{8}(\mathrm{M}=652.41 \mathrm{~g} / \mathrm{mol})$ : C 55.26, H 3.86; found: C 55.26, H 3.79. IR (ATR): $v\left(\mathrm{~cm}^{-1}\right)=638.41(\mathrm{~m}) ; 675.06(\mathrm{w}) ; 717.49(\mathrm{~m}) ; 758.01$ (vs); 858.29 (s); 958.58 (m); $1062.74(\mathrm{w}) ; 1105.17(\mathrm{w}) ; 1141.82(\mathrm{~m}) ; 1176.53(\mathrm{~m}) ; 1236.32(\mathrm{~m}) ; 1284.54(\mathrm{~m})$; 1307.69 (m); 1375.29 (vs); 1529.85 (s); 1585.43 (s); 1602.78 (s); 2929.76 (w); 2987.62 (w); 3620.25 (w).

[CeL( $\left.\left(\mathrm{H}_{2} \mathrm{O}\right)_{2}\right]_{\mathrm{n}}$ (2): Yield 88\%; Elemental analysis calcd. (\%) for $\mathrm{C}_{30} \mathrm{H}_{25} \mathrm{CeO}_{8}(\mathrm{M}=653.63 \mathrm{~g} / \mathrm{mol}): \mathrm{C}$ 55.13; H 3.86 found C 55.83, H 3.92. IR (ATR): $v\left(\mathrm{~cm}^{-1}\right)=638.42(\mathrm{w}) ; 715.57(\mathrm{~m}) ; 758.01(\mathrm{~s}) ; 796.58(\mathrm{~m})$; $862.16(\mathrm{~m}) ; 958.60(\mathrm{w}) ; 1016.46(\mathrm{~m}) ; 1037.68(\mathrm{w}) ; 1101.33(\mathrm{w}) ; 1139.90(\mathrm{w}) ; 1176.55(\mathrm{~m}) ; 1276.85(\mathrm{~m})$; 1305.78 (m); 1406.07 (vs); 1523.73 (s); 1583.52 (s); 1608.59 (s); 2922.09 (w); 3429.35 (w); 3616.44 (w).

[NdL( $\left.\left.\mathrm{H}_{2} \mathrm{O}\right)_{2}\right] \cdot 1.33 \mathrm{DMF} \cdot 2 \mathrm{H}_{2} \mathrm{O}$ (3): Yield: 84\%; Elemental analysis calcd. (\%) for $\mathrm{C}_{34} \mathrm{H}_{38.3} \mathrm{O}_{11.33} \mathrm{~N}_{1.33} \mathrm{Nd}$ $(M=791.21 \mathrm{~g} / \mathrm{mol}): \mathrm{C} 51.59, \mathrm{H} 4.87 ; \mathrm{N} 2.35$ found: C 52.30, H 4.57, N 2.56. IR (ATR): $v\left(\mathrm{~cm}^{-1}\right)=638.41$ (m); 675.06 (w); $715.76(\mathrm{~m}) ; 758.01(\mathrm{~s}) ; 796.57$ (m); 862.15 (s); 958.58 (m); 1016.45 (m); 1101.31 (m); 1139.89 (w); 1176.53 (m); 1267.53 (m); 1305.76 (m); 1382.91 (vs); 1402.2 (vs); 1523.71 (s); 1581.57 (s); 1604.71 (s); $2923.37(\mathrm{w}) ; 3627.96(\mathrm{w})$.

[EuL( $\left.\left(\mathrm{H}_{2} \mathrm{O}\right)_{2}\right] \cdot 1.33 \mathrm{DMF} \cdot 2 \mathrm{H}_{2} \mathrm{O}$ (4): Yield: 66\%; Elemental analysis calcd. (\%) for $\mathrm{C}_{34} \mathrm{H}_{38.3} \mathrm{O}_{11.33} \mathrm{~N}_{1.33} \mathrm{Eu}$ $(M=797.09 \mathrm{~g} / \mathrm{mol}):$ C 51.08, H 4.83, N 2.33 (calc idem Nd), found C 51.45, H 5.01; N 2.50. IR (ATR): $v$ $\left(\mathrm{cm}^{-1}\right)=640.34(\mathrm{~m}) ; 715.56(\mathrm{~s}) ; 758(\mathrm{vs}) ; 790.79(\mathrm{w}) ; 864.08(\mathrm{~s}) ; 958.58(\mathrm{~m}) ; 1022.53(\mathrm{~m}) ; 1203.24(\mathrm{~m})$; 1141.82 (m); 1176.53 (m); 1240.18 (m); 1280.68 (m); 1307.69 (m); 1377.12 (vs); 1402.02 (vs); 1519.85 (s); 1583.5 (s); 1583.5 (s); 1606.71 (s); 2927.83 (w); 2981.83 (w); 3649.18 (w).

[GdL( $\left.\left.\mathrm{H}_{2} \mathrm{O}\right)_{2}\right] \cdot 2 \mathrm{DMF} \cdot 2 \mathrm{H}_{2} \mathrm{O}$ (5): Yield: 82\%; Elemental analysis calcd. (\%) for $\mathrm{C}_{36} \mathrm{H}_{43} \mathrm{~N}_{2} \mathrm{O}_{12} \mathrm{Gd}$ $(M=852.98 \mathrm{~g} / \mathrm{mol}):$ C 50.69, H 5.08, N 3.28, found C 50.87, H 4.75; N 3.85. IR (ATR): $v\left(\mathrm{~cm}^{-1}\right)$ $=640.33(\mathrm{~m}) ; 675.04(\mathrm{w}) ; 715.55$ (s); $757.98(\mathrm{vs}) ; 794.62(\mathrm{~m}) ; 864.06(\mathrm{~s}) ; 958.56(\mathrm{~m}) ; 1016.42(\mathrm{~m}) ; 1103.21$ (m); 1143.72 (m); 1176.50 (m); 1245.94 (m); 1278.73 (m); 1303.80 (m); 1384.80 (vs); 1406.02 (vs); 1514.03 (s); 1527.53 (s); 1606.67 (s); $1934.748(w) ; 2923.63(w) ; 3039.63(w) ; 3406.08$ (w); 3616.31 (w); 3652.95 (w). 
[DyL $\left.\left(\mathrm{H}_{2} \mathrm{O}\right)_{2}\right]_{\mathrm{n}}$ (6): Yield: 77\%; Elemental analysis calcd. (\%) for $\mathrm{C}_{30} \mathrm{H}_{25} \mathrm{O}_{8} \mathrm{Dy}(M=677.08 \mathrm{~g} / \mathrm{mol})$ : C 53.30, H 3.73; found: C 53.81, H 4.08. IR (ATR): $v\left(\mathrm{~cm}^{-1}\right)=639.33(\mathrm{~m}) ; 715.55$ (m); 757.98 (s); 794.65 (m); 865.98 (s); 958.56 (w); 1016.42 (m); 1101.21 (m); 1141.72 (m); 1176.50 (m); 1278.72 (m); 1377.09 (vs); 1583.46 (s); 1936.48 (w); $2854.44(\mathrm{w}) ; 2921.9(\mathrm{w}) ; 3419.65(\mathrm{w}) ; 3508.37$ (m).

[HoL $\left.\left(\mathrm{H}_{2} \mathrm{O}\right)_{2}\right] \cdot 1.33 \mathrm{DMF} \cdot 2 \mathrm{H}_{2} \mathrm{O}$ (7): Yield 45\%; Elemental analysis calcd. (\%) for $\mathrm{C}_{34} \mathrm{H}_{38.3} \mathrm{O}_{11.33} \mathrm{~N}_{1.33} \mathrm{Ho}$ $(M=810.06 \mathrm{~g} / \mathrm{mol}):$ C 50.26, H 4.76, N 2.22, found: C 50.73, H 5.06., N 2.90. IR (ATR): $v\left(\mathrm{~cm}^{-1}\right)=$ 640.33 (m); 715.55 (s); 757.98 (vs); 794.65 (m); 865.98 (s); 958.56 (w); 1016.42 (m); 1016.21 (m) 1103.21 (m); 1143.72 (m); 1176.50 (m); 1278.72 (m); 1305.73 (m);1376.02 (vs) 1527.53 (s); 1583.46 (vs); 1814.9 (vw); 1936.48 (w); 2281.65 (vw); 2559.38 (vw); $2856.40(\mathrm{w}) ; 2923.9(\mathrm{w}) ; 3425.37$ (w); $3514.09(\mathrm{w})$.

\subsection{Synthesis of 2-Naphthyl Acetate}

A mixture of the substrate, 2-naphthol $(0.07 \mathrm{~g}, 0.48 \mathrm{mmol})$, acetic anhydride $(0.07 \mathrm{~g}, 0.72 \mathrm{mmol}$, 1.5 equiv.), and Ln-MOFs as the catalyst ( $1 \mathrm{~mol} \%$ - related to substrate) was stirred at room temperature with $\mathrm{CHCl}_{3}(2 \mathrm{~mL})$ as the solvent for one day. The catalyst was collected by filtration and the organic phase was washed successively with $2 \%$ aqueous $\mathrm{NaOH}(5 \mathrm{~mL})$ and saturated $\mathrm{NaCl}$ solution $(5 \mathrm{~mL})$. After drying with $\mathrm{MgSO}_{4}$, filtration and evaporation of the solvent at reduced pressure, the solid product was isolated and analyzed (yellowish powder; Mp: $72{ }^{\circ} \mathrm{C}$-lit. $71{ }^{\circ} \mathrm{C}$ [61]). Yield 98\% (3 as catalyst). ${ }^{1} \mathrm{H} \mathrm{NMR}\left(\mathrm{CDCl}_{3}-\mathrm{d}_{3}, 400.1 \mathrm{MHz}, \mathrm{ppm}\right): \delta=7.89-7.86(\mathrm{~m}, 2 \mathrm{CH}) ; 7.84-7.82(\mathrm{~m}, \mathrm{CH}$; $\left.{ }^{3} \mathrm{~J}_{\mathrm{H}, \mathrm{H}}=7.9 \mathrm{~Hz}\right) ; 7.61\left(\mathrm{~d}, \mathrm{CH} ;{ }^{3} \mathrm{~J}_{\mathrm{H}, \mathrm{H}}=2.3 \mathrm{~Hz}\right) ; 7.51(\mathrm{~m}, 2 \mathrm{CH}) ; 7.27\left(\mathrm{dd}, \mathrm{CH}^{3} \mathrm{~J}_{\mathrm{H}, \mathrm{H}}=9.03 \mathrm{~Hz}\right) ; 2.38\left(\mathrm{~s}, \mathrm{CH}_{3}\right)$. ${ }^{13} \mathrm{C} \mathrm{NMR}\left(\mathrm{CDCl}_{3}-\mathrm{d}, 100.6 \mathrm{MHz}, \mathrm{ppm}\right) ; \delta=169.7 ; 148.3 ; 133.7 ; 131.4 ; 129.3 ; 127.7 ; 127.6 ; 126.5 ; 125.7$; $121.1 ; 118.5 ; 21.2$.

\subsection{Crystal Structure Determination}

X-ray diffraction measurements were carried out with an Oxford-Diffraction Xcalibur E CCD diffractometer equipped with graphite-monochromated MoK $\alpha$ radiation. Single crystals were positioned at $40 \mathrm{~mm}$ from the detector and 163, 157, and 257 frames were measured each for 70,10 , and 75 s over a $1^{\circ}$ scan width for $\mathbf{1}, \mathbf{2}$, and 3 , respectively. The unit cell determination and data integration were carried out using the CrysAlis package of Oxford Diffraction [62]. The structures were solved by direct methods using Olex2 [63] and refined by full-matrix least-squares on $F^{2}$ with SHELXL-2015 [64] using an anisotropic model for non-hydrogen atoms. The positional parameters for $\mathrm{H}$ atoms attached to $\mathrm{C}$ atoms were introduced in idealized positions $\left(\mathrm{d}_{\mathrm{CH}}=0.96 \AA\right)$ using the riding model with their isotropic displacement parameters fixed at $120 \%$ of their riding atom. Positional parameters of the $\mathrm{H}$ attached to $\mathrm{O}$ atoms were obtained from different Fourier syntheses and verified by the geometric parameters of the corresponding hydrogen bonds. Crystal structures $\mathbf{1}$ and $\mathbf{2}$ contained large areas of disordered solvent molecules that could not be localized. In these cases, the contribution of disordered solvent molecules to structure factors was extracted using the "Solvent Mask" tool available in Olex2. Crystals of 3 were found to be a non-merohedral twin with two components related by $180^{\circ}$ rotation about the [100] direct lattice direction. The twin component ratio was refined at 0.52:0.48. The molecular plots were obtained using the Olex2 program. The crystallographic data and refinement details are quoted in Table 3, while bond lengths are summarized in Tables S2-S4 (Supplementary Materials). CCDC-1904154 (1), CCDC-1904155 (2), and CCDC-1904156 (3) contain the supplementary crystallographic data for this contribution. These data can be obtained free of charge via www.ccdc.cam.ac.uk/conts/retrieving.html (or from the Cambridge Crystallographic Data Center, 12 Union Road, Cambridge CB2 1EZ, UK; fax: (+44) 1223-336-033; or deposit@ccdc.ca.ac.uk). 
Table 3. Crystal data and details of the data collection for 1-3.

\begin{tabular}{|c|c|c|c|}
\hline Compound & $3984(1)$ & $3971(2)$ & $3972(3)$ \\
\hline empirical formula & $\mathrm{C}_{30} \mathrm{H}_{25} \mathrm{LaO}_{8}$ & $\mathrm{C}_{30} \mathrm{H}_{25} \mathrm{CeO}_{8}$ & $\mathrm{C}_{34} \mathrm{H}_{38.33} \mathrm{~N}_{1.33} \mathrm{NdO}_{11.33}$ \\
\hline$F w$ & 652.41 & 653.62 & 791.21 \\
\hline space group & Pnna & Pnna & $P 2_{1} / n$ \\
\hline$a[\AA]$ & $9.3345(5)$ & $9.5029(6)$ & $9.5200(13)$ \\
\hline$b[\AA]$ & 16.6700(9) & $16.6504(10)$ & $16.473(3)$ \\
\hline$c[\AA]$ & 27.2304(19) & 27.1399(15) & $27.389(6)$ \\
\hline$a\left[^{\circ}\right]$ & 90 & 90 & 90 \\
\hline$B\left[^{\circ}\right]$ & 90 & 90 & $93.098(18)$ \\
\hline$g\left[{ }^{\circ}\right]$ & 90 & 90 & 90 \\
\hline$V\left[\AA^{3}\right]$ & $4237.2(4)$ & $4294.3(4)$ & $4288.9(13)$ \\
\hline Z & 4 & 4 & 4 \\
\hline$r_{\text {calcd }}\left[\mathrm{g} \mathrm{cm}^{-3}\right]$ & 1.023 & 1.011 & 1.225 \\
\hline Crystal size [mm] & $0.20 \times 0.20 \times 0.10$ & $0.40 \times 0.20 \times 0.20$ & $0.70 \times 0.60 \times 0.18$ \\
\hline$T[\mathrm{~K}]$ & 180 & 293 & 180 \\
\hline$\mu\left[\mathrm{mm}^{-1}\right]$ & 1.040 & 1.092 & 1.260 \\
\hline $2 \mathrm{E}$ range & 5.11 to 50.054 & 4.542 to 50.052 & 2.886 to 50.054 \\
\hline Reflections collected & 9929 & 9514 & 11840 \\
\hline Independent reflections & $3744\left[R_{\mathrm{int}}=0.0515\right]$ & $3780\left[R_{\mathrm{int}}=0.0952\right]$ & $11840\left[R_{\mathrm{int}}=0.1178\right]$ \\
\hline Data/restraints/parameters & $3744 / 54 / 181$ & $3780 / 12 / 180$ & $11840 / 48 / 439$ \\
\hline$R_{1}{ }^{[\mathrm{a}]}$ & 0.0852 & 0.0538 & 0.0651 \\
\hline$w R_{2}[\mathrm{~b}]$ & 0.2280 & 0.0983 & 0.1431 \\
\hline $\mathrm{GOF}^{[\mathrm{c}]}$ & 1.048 & 1.002 & 1.040 \\
\hline Largest diff. peak/hole/e $\AA^{-3}$ & $1.16 /-1.45$ & $1.23 /-1.58$ & $1.40 /-1.00$ \\
\hline
\end{tabular}

${ }^{[\mathrm{a}]} R_{1}=\Sigma|| F_{\mathrm{o}}|-| F_{\mathrm{c}}|/ \Sigma| F_{\mathrm{o}} \mid \cdot{ }^{[\mathrm{b}]} w R_{2}=\left\{\Sigma\left[w\left(F_{\mathrm{o}}{ }^{2}-F_{\mathrm{c}}{ }^{2}\right)^{2}\right] / \Sigma\left[w\left(F_{\mathrm{o}}{ }^{2}\right)^{2}\right]\right\}^{1 / 2} .{ }^{[\mathrm{c}]} \mathrm{GOF}=\left\{\Sigma\left[w\left(F_{\mathrm{o}}{ }^{2}-F_{\mathrm{c}}{ }^{2}\right)^{2}\right] /(n-p)\right\}^{1 / 2}$, where $n$ is the number of reflections and $p$ is the total number of parameters refined.

\section{Conclusions}

A series of new lanthanide metal-organic frameworks with the general formula $\left[\mathrm{LnL}\left(\mathrm{H}_{2} \mathrm{O}\right)_{2}\right]_{\mathrm{n}}$ (where $\mathrm{Ln}=\mathrm{La}, \mathrm{Ce}, \mathrm{Nd}, \mathrm{Eu}, \mathrm{Gd}, \mathrm{Dy}$ and $\mathrm{Ho}$, and $\mathrm{L}=$ deprotonated 1,3,5-tris(4-carboxyphenyl)-2,4,6-trimethylbenzene) were synthesized. The crystal structures of the $\mathrm{La}(\mathrm{III}), \mathrm{Ce}(\mathrm{III})$, and $\mathrm{Nd}(\mathrm{III})$ complexes were successfully studied by the single-crystal diffraction method. It was demonstrated that all of these compounds showed high thermal stability (up to $\sim 480{ }^{\circ} \mathrm{C}$ ), while the gas sorption studies indicated good permanent porosity with SBET up to $\sim 400 \mathrm{~m}^{2} / \mathrm{s}$. The catalytic activity for a model reaction, namely $O$-acetylation was also evaluated and it was found that the synthesized MOFs successfully catalyzed the acetylation of 2-napthol. The novel $\left[\operatorname{LnL}\left(\mathrm{H}_{2} \mathrm{O}\right)_{2}\right]_{n}$ MOFs can serve as promising materials for gas storage as well as for heterogeneous catalysis.

Supplementary Materials: The following are available online, Synthesis of the ligand 1,3,5-tris(4-carboxyphenyl)-2,4,6-trimethylbenzene $\left(\mathrm{H}_{3} \mathrm{~L}\right)$ and of Ln-MOFs compounds (1-7). Table S1: Overview of the experimental details for the synthesis of 1-7. Figure S1: Optical microscopy image of 1-7, with Leica ICC50 W, 4x/0.10. Figure S2: IR spectrum of ligand $\mathrm{H}_{3} \mathrm{~L}$. Figure S3: IR spectrum of compound $\left[\mathrm{LaL}\left(\mathrm{H}_{2} \mathrm{O}\right)_{2}\right]_{n}(\mathbf{1})$. Figure S4: IR spectrum of compound $\left[\mathrm{CeL}\left(\mathrm{H}_{2} \mathrm{O}\right)_{2}\right]_{n}$ (2). Figure S5: IR spectrum of compound $\left[\mathrm{NdL}\left(\mathrm{H}_{2} \mathrm{O}\right)_{2}\right]_{n} \cdot 1.33 \mathrm{DMF} \cdot 2 \mathrm{H}_{2} \mathrm{O}$ (3). Figure S6: IR spectrum of compound $\left[\mathrm{EuL}\left(\mathrm{H}_{2} \mathrm{O}\right)_{2}\right]_{n} \cdot 1.33 \mathrm{DMF} \cdot 2 \mathrm{H}_{2} \mathrm{O}(4)$. Figure S7: IR spectrum of compound $\left[\mathrm{GdL}\left(\mathrm{H}_{2} \mathrm{O}\right)_{2}\right]_{n} \cdot 2 \mathrm{DMF} \cdot 2 \mathrm{H}_{2} \mathrm{O}(5)$. Figure S8: IR spectrum of compound $\left[\mathrm{DyL}\left(\mathrm{H}_{2} \mathrm{O}\right)_{2}\right]_{n}$ (6). Figure S9: IR spectrum of compound $\left[\mathrm{HoL}\left(\mathrm{H}_{2} \mathrm{O}\right)_{2}\right]_{n} \cdot 1.33 \mathrm{DMF} \cdot 2 \mathrm{H}_{2} \mathrm{O}(7)$. Figure S10: PXRD patterns of the two isostructural compounds $\left[\mathrm{LaL}\left(\mathrm{H}_{2} \mathrm{O}\right)_{2}\right]_{n}(\mathbf{1})$ and $\left[\mathrm{CeL}\left(\mathrm{H}_{2} \mathrm{O}\right)_{2}\right]_{n}(2)$ recorded at different times (6 min and $30 \mathrm{~min})$. Figure S11: PXRD patterns of $\left[\mathrm{LaL}\left(\mathrm{H}_{2} \mathrm{O}\right)_{2}\right]_{\mathrm{n}}(\mathbf{1})$ recorded at different times $(6 \mathrm{~min}$ and $30 \mathrm{~min})$. Figure S12: PXRD patterns of $\left[\mathrm{LaL}\left(\mathrm{H}_{2} \mathrm{O}\right)_{2}\right]_{n}$ (2). Figure S13: PXRD patterns of $\left[\mathrm{NdL}\left(\mathrm{H}_{2} \mathrm{O}\right)_{2}\right]_{n} \cdot 1.33 \mathrm{DMF} \cdot 2 \mathrm{H}_{2} \mathrm{O}$ (3). Figure S14: PXRD patterns of compound $\left[\mathrm{NdL}\left(\mathrm{H}_{2} \mathrm{O}\right)_{2}\right]_{n} \cdot 1.33 \mathrm{DMF} \cdot 2 \mathrm{H}_{2} \mathrm{O}(3)$-red, compound 3 after basic condition-black; compound 3 after acidic condition-green. Figure S15: PXRD patterns of activated compound $\left[\mathrm{NdL}\left(\mathrm{H}_{2} \mathrm{O}\right)_{2}\right]_{n} \cdot 1.33 \mathrm{DMF} \cdot 2 \mathrm{H}_{2} \mathrm{O}$ (3)-black and compound (3) after catalytic reaction (first cycle) -red and (3) -blue, after third cycle in catalytic processes. Figure S16: PXRD patterns of $\left[\text { EuL }\left(\mathrm{H}_{2} \mathrm{O}\right)_{2}\right]_{n} \cdot 1.33 \mathrm{DMF} \cdot 2 \mathrm{H}_{2} \mathrm{O}(4)$. Figure S17: PXRD patterns of $\left[\mathrm{GdL}\left(\mathrm{H}_{2} \mathrm{O}\right)_{2}\right]_{n} \cdot 2 \mathrm{DMF} \cdot 2 \mathrm{H}_{2} \mathrm{O}(5)$. Figure S18: PXRD patterns of $\left[\mathrm{DyL}\left(\mathrm{H}_{2} \mathrm{O}\right)_{2}\right]_{\mathrm{n}}$ (6). Figure S19: PXRD patterns of $\left[\mathrm{HoL}\left(\mathrm{H}_{2} \mathrm{O}\right)_{2}\right]_{n} \cdot 1.33 \mathrm{DMF} \cdot 2 \mathrm{H}_{2} \mathrm{O}$ (7). Figure S20: PXRD patterns of all compounds (1-7). Figure S21: Thermogravimetric analysis of ligand $\mathrm{H}_{3} \mathrm{~L}$. Figure S22: Thermogravimetric analysis of compound $\left[\mathrm{LaL}\left(\mathrm{H}_{2} \mathrm{O}\right)_{2}\right]_{\mathrm{n}}(\mathbf{1})$. Figure S23: Thermogravimetric analysis of compound $\left[\mathrm{CeL}\left(\mathrm{H}_{2} \mathrm{O}\right)_{2}\right]_{\mathrm{n}}$ 
(2). Figure S24: Thermogravimetric analysis of compound $\left[\mathrm{NdL}\left(\mathrm{H}_{2} \mathrm{O}\right)_{2}\right]_{n} \cdot 1.33 \mathrm{DMF} \cdot 2 \mathrm{H}_{2} \mathrm{O}$ (3). Figure S25: Thermogravimetric analysis of compound $\left[\mathrm{EuL}\left(\mathrm{H}_{2} \mathrm{O}\right)_{2}\right]_{n} \cdot 1.33 \mathrm{DMF} \cdot 2 \mathrm{H}_{2} \mathrm{O}(4)$. Figure S26: Thermogravimetric analysis of compound $\left[\mathrm{GdL}\left(\mathrm{H}_{2} \mathrm{O}\right)_{2}\right]_{n} \cdot 2 \mathrm{DMF} \cdot 2 \mathrm{H}_{2} \mathrm{O}(5)$. Figure S27: Thermogravimetric analysis of compound $\left[\mathrm{DyL}\left(\mathrm{H}_{2} \mathrm{O}\right)_{2}\right]_{n} \cdot(6)$. Figure S28: Thermogravimetric analysis of compound $\left[\mathrm{HoL}\left(\mathrm{H}_{2} \mathrm{O}\right)_{2}\right]_{n} \cdot 1.33 \mathrm{DMF} \cdot 2 \mathrm{H}_{2} \mathrm{O}(7)$. Figure S29: Thermogravimetric analysis of 2-naphyl acetate. Figure S30: Nitrogen sorption isotherms of $\left[\mathrm{LaL}\left(\mathrm{H}_{2} \mathrm{O}\right)_{2}\right]_{\mathrm{n}}(\mathbf{1})$ recorded at $77 \mathrm{~K}$. Filled symbols are for adsorption, empty symbols are for desorption $\left(\mathrm{SBET}=405 \mathrm{~m}^{2} / \mathrm{g}\right)$. Figure S31: Nitrogen sorption isotherms of $\left[\mathrm{CeL}\left(\mathrm{H}_{2} \mathrm{O}\right)_{2}\right]_{\mathrm{n}}(2)$ recorded at $77 \mathrm{~K}$. Filled symbols are for adsorption, empty symbols are for desorption $\left(\mathrm{SBET}=467 \mathrm{~m}^{2} / \mathrm{g}\right)$. Figure S32: Nitrogen sorption isotherms of $\left[\mathrm{NdL}\left(\mathrm{H}_{2} \mathrm{O}\right)_{2}\right]_{\mathrm{n}} \cdot 1.33 \mathrm{DMF} \cdot 2 \mathrm{H}_{2} \mathrm{O}(3)$ recorded at $77 \mathrm{~K}$. Filled symbols are for adsorption, empty symbols are for desorption $\left(\mathrm{SBET}=426 \mathrm{~m}^{2} / \mathrm{g}\right.$ ). Figure S33: Nitrogen sorption isotherms of $\left[\mathrm{EuL}\left(\mathrm{H}_{2} \mathrm{O}\right)_{2}\right]_{n} \cdot 1.33 \mathrm{DMF} \cdot 2 \mathrm{H}_{2} \mathrm{O}(4)$. Filled symbols are for adsorption, empty symbols are for desorption (SBET $=114 \mathrm{~m}^{2} / \mathrm{g}$ ). Figure S34: Nitrogen sorption isotherms of $\left[\mathrm{GdL}\left(\mathrm{H}_{2} \mathrm{O}\right)_{2}\right]_{n} \cdot 2 \mathrm{DMF} \cdot 2 \mathrm{H}_{2} \mathrm{O}(5)$ recorded at $77 \mathrm{~K}$. Filled symbols are for adsorption, empty symbols are for desorption (SBET $=348 \mathrm{~m}^{2} / \mathrm{g}$ ). Figure S35: (a) Nitrogen sorption isotherms of $\left[\mathrm{DyL}\left(\mathrm{H}_{2} \mathrm{O}\right)_{2}\right]_{\mathrm{n}}$ (6). Filled symbols are for adsorption, empty symbols are for desorption (SBET $=202 \mathrm{~m}^{2} / \mathrm{g}$ ), (b) Nitrogen sorption isotherms of $\left[\mathrm{DyL}\left(\mathrm{H}_{2} \mathrm{O}\right)_{2}\right]_{n}$ (6) (different synthesis, the same conditions). Filled symbols are for adsorption, empty symbols are for desorption $\left(\right.$ SBET $=298 \mathrm{~m}^{2} / \mathrm{g}$ ). Figure S36: Nitrogen sorption isotherms of $\left[\mathrm{HoL}\left(\mathrm{H}_{2} \mathrm{O}\right)_{2}\right]_{n} \cdot 1.33 \mathrm{DMF} \cdot 2 \mathrm{H}_{2} \mathrm{O}(7)$. Filled symbols are for adsorption, empty symbols are for desorption $\left(\mathrm{SBET}=286 \mathrm{~m}^{2} / \mathrm{g}\right)$. Figure S37: Fluorescence imaging of representative samples (Ligand; C1-7) excited with (a) green light, or (b) UV Objective 20x. Table S2: Bond distances $(\AA)$ and angles $\left({ }^{\circ}\right)$ for shI_3971_BeDa. Table S3: Bond distances $(\AA)$ and angles $\left({ }^{\circ}\right)$ for shI_3972_BeDa. Table S4: Bond distances $(\AA ̊)$ and angles $\left(^{\circ}\right)$ for shI_3984_BeDa.

Author Contributions: D.B. performed the experiments, interpreted the data, and evaluated the results, writing-review and editing the manuscript; L.G.B. provided the ligand, experimental data acquisition, and analysis; S.S. provided the x-ray data expertise, writing and review; N.L.M. conducted the TG data analysis, project administration, and funding acquisition; Ü.K.-D. conducted the PXRD analysis; V.L. undertook the review process; C.J. conducted the scientific validation and manuscript revision. All authors discussed the results, commented on the manuscript, and have read and agreed to the published version of the manuscript.

Funding: The financial support of European Social Fund for Regional Development, Competitiveness Operational Program Axis 1-Project "Novel Porous Coordination Polymers with Organic Ligands of Variable Length for Gas Storage", POCPOLIG (ID P_37_707, Contract 67/08.09.2016, cod MySMIS: 104810) is gratefully acknowledged.

Conflicts of Interest: The authors declare no conflicts of interest.

\section{References}

1. Chen, Y.; Ma, S. Microporous lanthanide metal-organic frameworks. Rev. Inorg. Chem. 2012, 32, 81-100. [CrossRef]

2. Zhu, L.; Liu, X.-Q.; Jiang, H.-L.; Sun, L.-B. Metal-Organic Frameworks for Heterogeneous Basic Catalysis. Chem. Rev. 2017, 117, 8129-8176. [CrossRef] [PubMed]

3. Janiak, C.; Vieth, J.K. MOFs, MILs and more: Concepts, properties and applications for porous coordination networks (PCNs). New J. Chem. 2010, 34, 2366. [CrossRef]

4. Zhou, H.-C.; Kitagawa, S. Metal-Organic Frameworks (MOFs). Chem. Soc. Rev. 2014, 43, 5415-5418. [CrossRef]

5. Slater, A.G.; Cooper, A.I. Function-led design of new porous materials. Science 2015, 348, aaa8075. [CrossRef] [PubMed]

6. Cheong, V.F.; Moh, P.Y. Recent advancement in metal-organic framework: Synthesis, activation, functionalisation, and bulk production. Mater. Sci. Technol. 2018, 34, 1025-1045. [CrossRef]

7. Li, H.; Eddaoudi, M.; O'Keeffe, M.; Yaghi, O.M. Design and synthesis of an exceptionally stable and highly porous metal-organic framework. Nature 1999, 402, 276-279. [CrossRef]

8. Furukawa, H.; Cordova, K.E.; O'Keeffe, M.; Yaghi, O.M. The Chemistry and Applications of Metal-Organic Frameworks. Science 2013, 341, 1230444. [CrossRef]

9. Liu, S.; Zhang, J.-W.; Wang, X.; Wei, Y.-B. Synthesis, Crystal Structure and Catalytic Property of a New Cadmium Coordination Polymer. J. Clust. Sci. 2017, 38, 1294-1962. [CrossRef]

10. Yoon, M.; Srirambalaji, R.; Kim, K. Homochiral Metal-Organic Frameworks for Asymmetric Heterogeneous Catalysis. Chem. Rev. 2011, 112, 1196-1231. [CrossRef]

11. Petit, C. Present and future of MOF research in the field of adsorption and molecular separation. Curr. Opin. Chem. Eng. 2018, 20, 132-142. [CrossRef]

12. Canepa, P.; Chabal, Y.J.; Thonhauser, T. When metal organic frameworks turn into linear magnets. Phys. Rev. B 2013, 87, 094407. [CrossRef] 
13. Gao, Q.; Xie, Y.-B.; Zhang, C.; Sun, J. Synthesis, structures, thermal and magnetic properties of a series of lanthanide [Ln $=\mathrm{Sm}, \mathrm{Gd}, \mathrm{Er}, \mathrm{Yb}$ ] complexes with 4-quinolineacarboxylate. J. Rare Earths 2009, 27, 12-17. [CrossRef]

14. Lustig, W.P.; Mukherjee, S.; Rudd, N.D.; Desai, A.V.; Li, J.; Ghosh, S.K. Metal-organic frameworks: Functional luminescent and photonic materials for sensing applications. Chem. Soc. Rev. 2017, 46, 3242-3285. [CrossRef] [PubMed]

15. Su, Y.; Yu, J.; Li, Y.; Phua, S.F.Z.; Liu, G.; Lim, W.Q.; Yang, X.; Ganguly, R.; Dang, C.; Yang, C.; et al. Versatile bimetallic lanthanide metal-organic frameworks for tunable emission and efficient fluorescence sensing. Commun. Chem. 2018, 1, 12. [CrossRef]

16. Cui, Y.; Zhang, J.; Chen, B.; Qian, G. Lanthanide Metal-Organic Frameworks for Luminescent Applications. In Handbook on the Physics and Chemistry of Rare Earths; Gschneidner, K.A., Jr., Eyring, L., Eds.; Elsevier BV: North-Holland, 2016; Volume 50, pp. 243-268.

17. Shen, L.; Yang, L.; Fan, Y.; Wang, L.; Xu, J. Construction of a series of lanthanide metal-organic frameworks: Synthesis, structure, luminescence and white light emission. Cryst. Eng. Comm. 2015, 17, 9363-9369. [CrossRef]

18. Huxford, R.C.; Della Rocca, J.; Lin, W. Metal-organic frameworks as potential drug carriers. Curr. Opin. Chem. Boil. 2010, 14, 262-268. [CrossRef] [PubMed]

19. He, C.; Lu, K.; Liu, D.; Lin, W. Nanoscale Metal-Organic Frameworks for the Co-Delivery of Cisplatin and Pooled siRNAs to Enhance Therapeutic Efficacy in Drug-Resistant Ovarian Cancer Cells. J. Am. Chem. Soc. 2014, 136, 5181-5184. [CrossRef] [PubMed]

20. Cai, W.; Wang, J.; Chu, C.; Chen, W.; Wu, C.; Liu, G. Metal-Organic Framework-Based Stimuli-Responsive Systems for Drug Delivery. Adv. Sci. 2018, 6, 1801526. [CrossRef]

21. Schoedel, A.; Yaghi, O.M. Porosity in metal-organic compounds. In Macrocyclic and Supramolecular Chemistry: How Izatt-Christensen Award Winners Shaped the Field, 1st ed.; Izatt, R.M., Ed.; John-Wiley \& Sons: West Sussex, UK, 2016; pp. 200-220.

22. McGuire, C.V.; Forgan, R.S. The surface chemistry of metal-organic frameworks. Chem. Commun. 2015, 51, 5199-5217. [CrossRef]

23. Furukawa, H.; Ko, N.; Go, Y.B.; Aratani, N.; Choi, S.B.; Choi, E.; Yazaydin, A.O.; Snurr, R.Q.; O’Keeffe, M.; Kim, J.; et al. Ultrahigh Porosity in Metal-Organic Frameworks. Science 2010, 329, 424-428. [CrossRef]

24. Chui, S.S. A Chemically Functionalizable Nanoporous Material $\left[\mathrm{Cu}_{3}(\mathrm{TMA})_{2}\left(\mathrm{H}_{2} \mathrm{O}\right)_{3}\right]_{n}$. Science 1999, 283, 1148-1150. [CrossRef] [PubMed]

25. Ameloot, R.; Gobechiya, E.; Uji-I, H.; Martens, J.A.; Hofkens, J.; Alaerts, L.; Sels, B.F.; De Vos, D.E. Direct Patterning of Oriented Metal-Organic Framework Crystals via Control over Crystallization Kinetics in Clear Precursor Solutions. Adv. Mater. 2010, 22, 2685-2688. [CrossRef] [PubMed]

26. Bano, S.; Tariq, S.R.; Ilyas, A.; Aslam, M.; Bilad, M.R.; Nizami, A.-S.; Khan, A.L. Synergistic solution of $\mathrm{CO}_{2}$ capture by novel lanthanide-based MOF-76 yttrium nanocrystals in mixed-matrix membranes. Energy Environ. 2019, 31, 692-712. [CrossRef]

27. Cheng, P.-C.; Li, B.-H.; Tseng, F.-S.; Liang, P.-C.; Lin, C.-H.; Liu, W.-R. Synthesis, Structures and Electrochemical Properties of Lithium 1,3,5-Benzenetricarboxylate Complexes. Polymers 2019, 11, 126. [CrossRef] [PubMed]

28. Zhao, X.; Liu, F.; Zhang, L.-L.; Sun, D.; Wang, R.; Ju, Z.; Yuan, D.; Sun, D. Achieving a Rare Breathing Behavior in a Polycatenated 2 D to 3 D Net through a Pillar-Ligand Extension Strategy. Chem. Eur. J. 2013, 20, 649-652. [CrossRef] [PubMed]

29. Vergadou, V.; Pistolis, G.; Michaelides, A.; Varvounis, G.; Siskos, M.; Boukos, N.; Skoulika, S. Self-Organization of Four Symmetric Tri-phenyl-benzene Derivatives. Cryst. Growth Des. 2006, 6, 2486-2492. [CrossRef]

30. Bajpai, A.; Venugopalan, P.; Moorthy, J.N. Self-Assembly of Rigid Three-Connecting Mesitylenetribenzoic Acid: Multifarious Supramolecular Synthons and Solvent-Induced Supramolecular Isomerism. Cryst. Growth Des. 2013, 13, 4721-4729. [CrossRef]

31. Qiu, Y.-C.; Yuan, S.; Li, X.-X.; Du, D.-Y.; Wang, C.; Qin, J.-S.; Drake, H.F.; Lan, Y.-Q.; Jiang, L.; Zhou, H.-C. Face-Sharing Archimedean Solids Stacking for the Construction of Mixed-Ligand Metal-Organic Frameworks. J. Am. Chem. Soc. 2019, 141, 13841-13848. [CrossRef]

32. Wang, X.; Zhang, X.; Li, P.; Otake, K.-I.; Cui, Y.; Lyu, J.; Krzyaniak, M.; Zhang, Y.; Li, Z.; Liu, J.; et al. Vanadium Catalyst on Isostructural Transition Metal, Lanthanide, and Actinide Based Metal-Organic Frameworks for Alcohol Oxidation. J. Am. Chem. Soc. 2019, 141, 8306-8314. [CrossRef] 
33. Guo, X.; Zhu, G.; Li, Z.; Sun, F.; Yang, Z.; Qiu, S. A lanthanide metal-organic framework with high thermal stability and available Lewis-acid metal sites. Chem. Commun. 2006, 3172-3174. [CrossRef]

34. Choi, J.R.; Tachikawa, T.; Fujitsuka, M.; Majima, T. Europium-Based Metal—Organic Framework as a Photocatalyst for the One-Electron Oxidation of Organic Compounds. Langmuir 2010, 26, 10437-10443. [CrossRef] [PubMed]

35. Lee, J.; Farha, O.K.; Roberts, J.M.; Scheidt, K.A.; Nguyen, S.T.; Hupp, J.T. Metal-organic framework materials as catalysts. Chem. Soc. Rev. 2009, 38, 1450-1459. [CrossRef] [PubMed]

36. Raizada, M.; Sama, F.; Ashafaq, M.; Shahid, M.; Khalid, M.; Ahmad, M.; Siddiqi, Z.A. Synthesis, structure and magnetic studies of lanthanide metal-organic frameworks (Ln-MOFs): Aqueous phase highly selective sensors for picric acid as well as the arsenic ion. Polyhedron 2018, 139, 131-141. [CrossRef]

37. Zhao, X.; He, H.; Dai, F.; Sun, D.; Ke, Y. Supramolecular Isomerism in Honeycomb Metal-Organic Frameworks Driven by $\mathrm{CH} \cdots \pi$ Interactions: Homochiral Crystallization from an Achiral Ligand through Chiral Inducement. Inorg. Chem. 2010, 49, 8650-8652. [CrossRef]

38. Wang, B.; Lv, X.-L.; Feng, D.; Xie, L.-H.; Zhang, J.; Li, M.; Xie, Y.; Li, J.-R.J.; Zhou, H.-C. Highly Stable $\mathrm{Zr}(\mathrm{IV})$-Based Metal-Organic Frameworks for the Detection and Removal of Antibiotics and Organic Explosives in Water. J. Am. Chem. Soc. 2016, 138, 6204-6216. [CrossRef]

39. Zhao, X.; Dou, J.; Sun, D.; Cui, P.; Sun, D.; Wu, Q. A porous metal-organic framework (MOF) with unusual 2D $\rightarrow$ 3D polycatenation based on honeycomb layers. Dalton Trans. 2012, 41, 1928-1930. [CrossRef]

40. Bumstead, A.M.; Cordes, D.B.; Dawson, D.M.; Chakarova, K.; Mihaylov, M.; Hobday, C.L.; Düren, T.; Hadjiivanov, K.I.; Slawin, A.M.Z.; Ashbrook, S.E.; et al. Modulator-Controlled Synthesis of Microporous STA-26, an Interpenetrated 8,3-Connected Zirconium MOF with the the-i Topology, and its Reversible Lattice Shift. Chem. Eur. J. 2018, 24, 6115-6126. [CrossRef]

41. Liu, T.-F.; Vermeulen, N.A.; Howarth, A.J.; Li, P.; Sarjeant, A.A.; Hupp, J.T.; Farha, O.K. Adding to the Arsenal of Zirconium-Based Metal-Organic Frameworks: The Topology as a Platform for Solvent-Assisted Metal Incorporation. Eur. J. Inorg. Chem. 2016, 2016, 4349-4352. [CrossRef]

42. Gustafsson, M.; Li, Z.; Zhu, G.; Qiu, S.; Grins, J.; Zou, X. A porous chiral lanthanide Metal-Organic Framework with high thermal stability. In Zeolites and Related materials: Trends, Targets and Chalenges; Gedeon, A., Massiani, P., Babonneau, F., Eds.; Elsevier BV: Amsternam, The Netherlands, 2008; Volume 174, pp. 451-454.

43. Thommes, M. Physical Adsorption Characterization of Nanoporous Materials. Chem. Ing. Tech. 2010, 82, 1059-1073. [CrossRef]

44. Thommes, M.; Kaneko, K.; Neimark, A.V.; Olivier, J.P.; Rodriguez-Reinoso, F.; Rouquerol, J.; Sing, K.S. Physisorption of gases, with special reference to the evaluation of surface area and pore size distribution (IUPAC Technical Report). Pure Appl. Chem. 2015, 87, 1051-1069. [CrossRef]

45. Mondal, S.S.; Dey, S.; Attallah, A.G.; Krause-Rehberg, R.; Janiak, C.; Holdt, H. Insights into the pores of microwave-assisted metal-imidazolate frameworks showing enhanced gas sorption. Dalton Trans. 2017, 46, 4824-4833. [CrossRef] [PubMed]

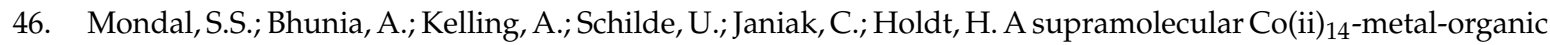
cube in a hydrogen-bonded network and a Co(ii)-organic framework with a flexible methoxy substituent. Chem. Commun. 2014, 50, 5441-5443. [CrossRef] [PubMed]

47. Mondal, S.S.; Dey, S.; Baburin, I.A.; Kelling, A.; Schilde, U.; Seifert, G.; Janiak, C.; Holdt, H.-J. Syntheses of two imidazolate-4-amide-5-imidate linker-based hexagonal metal-organic frameworks with flexible ethoxy substituent. Cryst. Eng. Comm. 2013, 15, 9394. [CrossRef]

48. Mondal, S.S.; Bhunia, A.; Baburin, I.A.; Jäger, C.; Kelling, A.; Schilde, U.; Seifert, G.; Janiak, C.; Holdt, H.-J. Gate effects in a hexagonal zinc-imidazolate-4-amide-5-imidate framework with flexible methoxy substituents and $\mathrm{CO}_{2}$ selectivity. Chem. Commun. 2013, 49, 7599. [CrossRef] [PubMed]

49. Alrefai, A.; Mondal, S.S.; Wruck, A.; Kelling, A.; Schilde, U.; Brandt, P.; Janiak, C.; Schönfeld, S.; Weber, B.; Rybakowski, L.; et al. Hydrogen-bonded supramolecular metal-imidazolate frameworks: Gas sorption, magnetic and UV/Vis spectroscopic properties. J. Incl. Phenom. Macrocycl. Chem. 2019, 94, 155-165. [CrossRef]

50. Mondal, S.S.; Dey, S.; Attallah, A.G.; Bhunia, A.; Kelling, A.; Schilde, U.; Krause-Rehberg, R.; Janiak, C.; Holdt, H. Missing Building Blocks Defects in a Porous Hydrogen-bonded Amide-Imidazolate Network Proven by Positron Annihilation Lifetime Spectroscopy. ChemistrySelect 2016, 1, 4320-4325. [CrossRef] 
51. Mondal, S.S.; Bhunia, A.; Attallah, A.G.; Matthes, P.R.; Kelling, A.; Schilde, U.; Müller-Buschbaum, K.; Krause-Rehberg, R.; Janiak, C.; Holdt, H. Study of the Discrepancies between Crystallographic Porosity and Guest Access into Cadmium-Imidazolate Frameworks and Tunable Luminescence Properties by Incorporation of Lanthanides. Chem. Eur. J. 2016, 22, 6905-6913. [CrossRef]

52. Binnemans, K. Lanthanide-Based Luminescent Hybrid Materials. Chem. Rev. 2009, 109, 4283-4374. [CrossRef]

53. You, L.-X.; Li, Z.-G.; Ding, F.; Wang, S.-J.; Ren, B.-Y.; Sun, Y.-G. Synthesis, structure and luminescence properties of lanthanide coordination polymers using in situ decarboxylation of a $\mathrm{H}_{3}$ cppdc ligand. Inorg. Chem. Commun. 2014, 46, 340-343. [CrossRef]

54. Dechnik, J.; Mühlbach, F.; Dietrich, D.; Wehner, T.; Gutmann, M.; Lühmann, T.; Meinel, L.; Janiak, C.; Müller-Buschbaum, K. Luminescent Metal-Organic Framework Mixed-Matrix Membranes from Lanthanide Metal-Organic Frameworks in Polysulfone and Matrimid. Eur. J. Inorg. Chem. 2016, 2016, 4408-4415. [CrossRef]

55. Kumar, M.; Sheikh, H.N.; Franconetti, A.; Zaręba, J.K.; Sahoo, S.C.; Frontera, A.; Franconetti, A. 2,5-Furandicarboxylic acid as a linker for lanthanide coordination polymers: The role of heteroaromatic $\pi-\pi$ stacking and hydrogen bonding. New J. Chem. 2019, 43, 2179-2195. [CrossRef]

56. Pagis, C.; Ferbinteanu, M.; Rothenberg, G.; Tanase, S.; Grecea, S.T. Lanthanide-Based Metal Organic Frameworks: Synthetic Strategies and Catalytic Applications. ACS Catal. 2016, 6, 6063-6072. [CrossRef]

57. Rahman, A.; Uahengo, V.; Likius, D.S.; Mupa, M. Selective Acetylation of 2-Naphthol to 2-Naphthyl Acetate with Ni Homogeneous Catalysts: An Environmentally Friendly Protocol. Sci. J. Chem. 2017, 5, 47. [CrossRef]

58. Herbst, A.; Khutia, A.; Janiak, C. Brønsted Instead of Lewis Acidity in Functionalized MIL-101Cr MOFs for Efficient Heterogeneous (nano-MOF) Catalysis in the Condensation Reaction of Aldehydes with Alcohols. Inorg. Chem. 2014, 53, 7319-7333. [CrossRef]

59. Chughtai, A.H.; Ahmad, N.; Younus, H.A.; Laypkov, A.; Verpoort, F. Metal-organic frameworks: Versatile heterogeneous catalysts for efficient catalytic organic transformations. Chem. Soc. Rev. 2015, 44, 6804-6849. [CrossRef]

60. Remya, V.R.; Kurian, M. Synthesis and catalytic applications of metal-organic frameworks: A review on recent literature. Int. Nano Lett. 2018, 9, 17-29. [CrossRef]

61. Zhao, Y.; Liu, L.; Chen, Z.; Li, T.; Jin, T. Rapid and Efficient Method for Acetylation of Alcohols and Phenols with Acetic Anhydride Catalyzed by Silica Sulfate. Synth. Commun. 2006, 36, 1221-1227. [CrossRef]

62. CrysAlisPro Software system, version 1.171.38.46; Rigaku Corporation: Oxford, UK, 2015.

63. Dolomanov, O.; Bourhis, L.J.; Gildea, R.; Howard, J.A.; Puschmann, H. OLEX2: A complete structure solution, refinement and analysis program. J. Appl. Crystallogr. 2009, 42, 339-341. [CrossRef]

64. Sheldrick, G.M. Crystal structure refinement with SHELXL. Acta Cryst. C 2015, 71, 3-8. [CrossRef]

Sample Availability: Samples of the compounds are not available from the authors.

(C) 2020 by the authors. Licensee MDPI, Basel, Switzerland. This article is an open access article distributed under the terms and conditions of the Creative Commons Attribution (CC BY) license (http://creativecommons.org/licenses/by/4.0/). 